\title{
水素が関与する破壊の特徴
}

\author{
南 雲 道 彦* \\ * 早稲田大学名誉教授
}

\section{Characteristic Features of Hydrogen-related Failure}

\author{
Michihiko Nagumo* \\ * Professor Emeritus, Waseda University
}

\begin{abstract}
Characteristics of hydrogen-related failure are reviewed from mostly experimentally observed features. Comparison with the failure under normal atmospheres is made so as to extract the way by which hydrogen plays a role in the fracture process. Fractographic features associated with plasticity and the promotion of the crack initiation and growth analyzed by means of an R-curve method are presented. Enhanced plastic instability is noted as a precursor of the failure. Effects of hydrogen on stress relaxation and creep are presented as the dislocation dynamics that operate on delayed fracture. Effects of environmental variation of applied stress and external hydrogen potential are also presented.
\end{abstract}

Key words : hydrogen embrittlement, ductile fracture, brittle fracture, fractography, R-curve, plastic instability, delayed fracture, stress relaxation, creep

\section{1. はじめに}

材料の破壊には塑性変形をほとんど伴わずに低応力で 突然破壊する脆性破壊, 塑性変形の進行に伴って材料内 部に微小ボイドの生成と成長・連結が進む延性破壊, 荷 重の繰り返しでき裂が発生して徐々に進展する疲労破 壊, 一定荷重下で塑性変形が起きて破壊にいたるクリー プ破壊，腐食環境で材料表面にき裂が生成して進展する 応力腐食割れなどいろいろなタイプがある。これらの破 壊のメカニズムや支配要因は材料の変形特性や使用され る条件によって異なるが，破壊とはすべて割れの発生と その成長・伝播による材料の分離であるという意味では 共通している. そして基本的には原子結合の引張り破断 と，せん断分離の 2 つに分類される.

「水素脆性」とは微量の水素によって材料の強度や延 性の低下，あるいは早期の破断が起きる現象を指してい るが，この用語は必ずしも破壊現象としての本質を表し ているものではない.「水素脆性」には水素が塑性変形 を介して寄与するという観点から，「水素が関係した破 壊」(hydrogen-related failure) や「水素助長割れ」 (hydrogen-assisted cracking) などの用語も用いられてい る. 用語は街学的な好みだけではなく, 現象の本質を正 確に表す上で重要であるが，「水素脆性」が一般的な用 語になっているので本報ではとりあえずそれに従うこと にする。

破壊特性が材料ごとに異なるのは割れの発生や成長を 組織因子や強度・変形特性が支配するためである。した がって, 耐水素脆性にすぐれる材料設計のためには, 破 壊過程，すなわち微小き裂の生成や成長のそれぞれの段 階で水素が組織因子や変形特性とどのように関わるのか を理解しなくてはならない。これを通して単に現象論的

于272-0827 市川市国府台1-8-10（1-8-10, Konodai, Ichikawa, 2720827 Japan)
に水素量と材料劣化の関係を調べるだけではなく，水素 脆性の実体と水素の役割が明確になることが期待され る.

水素脆性は引張りや曲げ，あるいは疲労などいろいろ な材料試験で表れ，用いられる試験片も平滑試料や切欠 き試料，そのサイズもいろいろである. 試料内部の応力 や歪みの状態はこれらの条件によって異なる。そこで, 水素脆化現象を統一的に理解する上で基本的に重要なス タンスは, 水素脆性を特異な破壊現象として捉えるので はなくて，一般的な破壊過程のどの局面が水素によって 強められているのかという認識である。したがって通常 の破壊現象との対比が重要であり, 本報では破壊の基本 事項を整理しながら水素脆性の特徵をまとめる.これら の結果をもとにした水素脆性の機構については次報で述 べる．また，基本的には水素が材料の変形特性に及ぼす 影響が重要であるが，いくつかの解説もある11-3) ので省 略し，必要な都度に触れることにする。

\section{2. 水素脆性破面の特徵}

\section{1 粒 内 破 壊}

\subsection{1 へき開破面}

割れの結晶粒内伝播を大別すると，塑性変形をあまり 伴わずに特定の結晶面に沿って急速に伝播するへき開破 壊と，大きな塑性変形を伴う延性破壊がある。塑性変形 には局所的な進行にも注目しなくてはならない．脆性破 壊は一般にき裂の表面エネルギーの増加が初期き裂のま わりにおける弾性エネルギーの増加よりも小さくなるこ とによってき裂進展が不安定化して急速に起きる現象で ある．脆性的なき裂進展には負荷応力の増加を必要とし ない. 脆性破壊の発生条件として Griffithの式があり， き裂先端で原子結合が引張り応力で切断されていくため にはき裂先端が原子オーダーで鋭くなくてはならない. 実際には，金属ではき裂先端に微小な塑性変形域が生成 することが多く，き裂先端は鈍化するが塑性域を含めて 
実効的なき裂長さとすることによって条件式は保たれる4).

体心立方晶の鉄鋼の低温脆性ではへき開破面が観察さ れることが多い。破面は $\{100\}$ 面に沿って全体としては 平坦であるが，割れの進行方向にほぼ沿ってリバーパ夕 ーンと呼ばれる筋模様を伴っているのが特徵である. 水 素脆性では Tetelman らが $3 \% \mathrm{Si}$ 鉄単結晶試料に水素添加 すると $\{100\}$ 面に沿う割れが生成することを報告し ${ }^{5)}$, 脆 性破壊であるとしている。この場合に外部負荷はかけら れていないが，割れの先端からすべり面である $\{110\}$ 及 び\{112\}面に沿って転位が生成していることをエッチピ ットから観察しており, 割れの成長は断続的に起きてい る。これはき裂内部に高圧の分子状水素が析出している ことを示唆しており，水素による内圧が外部応力に代わ る作用をしている。水素添加は $4 \mathrm{vol} \% \mathrm{H}_{2} \mathrm{SO}_{4}$ に微量の $\mathrm{CS}_{2}$ と $\mathrm{As}_{2} \mathrm{O}_{3}$ を水素侵入促進材として添加した液で 20 $\mathrm{mA} / \mathrm{cm}^{2}$ の電流密度の陰極電解, あるいは $700 \sim 1200^{\circ} \mathrm{C}$ の $0.125 \mathrm{MPa}$ の水素ガス䨌囲気に $1 \mathrm{~h}$ おいた後で水焼入 れの 2 つの方法を用いている. 破面は水素を予添加した 試料を引張り破断させた場合は低温脆性と同様である が, 水素添加しながら静荷重をかけて破断させる, いわ ゆる遅れ破壊では多数のわん曲したステップが表れると している.

寺崎らは鉄単結晶を用いて水素脆性破面の詳細な観察 を行っている ${ }^{6}$. サイドノッチ (深さ $1.5 \mathrm{~mm}$, 先端半径 $0.05 \mathrm{~mm}$ ) をつけた $0.014 \mathrm{mass} \% \mathrm{C}$ を含む単結晶試料（板 状：厚さ $1.2 \mathrm{~mm}$, 幅約 $4 \mathrm{~mm}$ ) を室温で水素添加しなが ら<100>方向に低速引張り破断をさせるとリバーパ夕 ーンを伴うへき開破面が観察されている。試料方位はへ き開破壊にもっとも有利であり，水素添加条件は $\mathrm{NaAsO}_{2}$ を添加した $0.05 \mathrm{~N} \mathrm{H}_{2} \mathrm{SO}_{4}$ を用いた陰極電解で電 流密度を $3 \mathrm{~mA} / \mathrm{mm}^{2}$ 以上にしている。ここで注目される 現象はへき開破壊の発生に先行して次項で述べる縞模様 を伴う特異な破面があることである。この縞模様破面が 生成した後で脱水素して引張りを続けた場合にはへき開 破壊は発生せず，へき開発生には水素の存在が必要であ る. また, $0.001 \mathrm{mass} \% \mathrm{C}$ の鉄単結晶試料ではへき開破 壞は観察されていない。

\subsection{2 縞状模様破面}

寺崎らの結果で水素脆性破面として特徽づけられるの は縞状模様で, striation-like hydrogen embrittlement (SHE) と名づけている. 図 16) は 0.001 mass\% C 単結晶 試料の破面の例で，マクロ的には（001）面上でき裂進展 方向と直角な縞模様は $\{112\}$ すべり面のトレースにほぼ 対応しており, 割れ先端は $<110>$ 方向に沿って進展し ている。この縞模様の部分を走査型トンネル顕微鏡 （STM）で凹凸を調べ，相対する破面を合わせてみると 図 1 の下部に模式的に示したように谷になっており，微 小空洞が $2,3 \mu \mathrm{m}$ の長さのトンネル状に出来ていると推 定される.この様相はすべり帯の活動が微小空洞の生成 に関係することを示唆している.

このような微細縞模様は以前にも $\mathrm{Si}$ 鉄で観察されてい る. Gerberich らは疲労き裂を入れた 3 mass $\% \mathrm{Si}$ 鉄単結 晶試料（直径 $23 \mathrm{~mm}$, 厚さ $4.8 \mathrm{~mm}$ ) を室温, $0.1 \mathrm{MPa}$ の 水素雾囲気中で $<001>$ 方向に引張りを行い, 割れ進展 速度の測定とともにアクースティックエミッション (AE) の検出を行っている7)。予き裂は $34 \mathrm{MPa} \cdot \mathrm{m}^{1 / 2}$ の応

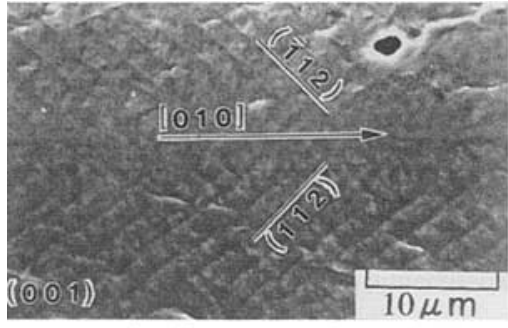

Crack initiation due to hydrogen at the slip band or cell wall

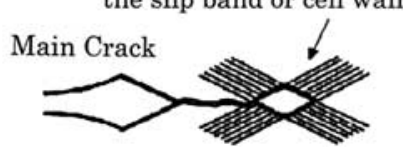

困 1 水素添加した純鉄単結晶破面に見られる縞状模様（上）と その STM 観察による凹凸の模式困 (下) ${ }^{6)}$

力拡大係数值で約 $100 \mu \mathrm{m}$ 進展し, その破面には図 1 に 類似した約 $1 \mu \mathrm{m}$ 間隔の周期的な縞模様がある。縞は割 れの進展方向に直交していて割れの段階的な停止線と考 えられるが，割れが進展するく $110>$ 方向に不規則では あるが縞と直角に別のステップが約 $5 \mu \mathrm{m}$ 程度の間隔で 存在している。このステップは割れが横に広がる際の分 離単位ではないかとされ, 微細へき開としているがそれ を裏づける結晶面の確認はない.

Gerberich らの測定では割れの進展は $\mathrm{AE}$ の発生を伴 っていて，数十の $\mathrm{AE}$ イベントが一つのグループとなっ ている. $\mathrm{AE}$ 発生数と縞との対応から, 一つの $\mathrm{AE}$ グルー プは筋ひとつ分の進展に, 個々の $\mathrm{AE}$ イベントは割れの 横への広がりに対応するとして, 測定された $\mathrm{AE}$ 発生時 間間隔から筋ひとつの進展は平均 $13 \mathrm{~s}$ 程度, 分離単位の 生成は約 $0.01 \mathrm{~s}$ の間隔で不連続に起きるとしている. $\mathrm{AE}$ は割れの横の広がりで発生するが，筋が前進するときに は発生しないことになる。この試料の降伏強さは 300 $\mathrm{MPa}$ で，予き裂先端から主に $\{110\}$ のすべりトレースが 観察されている. 破面はマクロ的には $\{100\}$ 面であるが, ミクロな進展はへき開面ではないことに注意が必要であ る.

さらに細かい縞模様の観察は Marrow らが粗粒 3 mass\% Si 鉄に電解水素添加したときに生成したブリス ターについて行っている8). 水素添加は $1 \mathrm{M} \mathrm{H}_{2} \mathrm{SO}_{4}+4$ $\mathrm{mg} / \mathrm{L} \mathrm{As}_{2} \mathrm{O}_{3}$ 液を用いた陰極電解で電流密度は $5 \mathrm{~mA} / \mathrm{cm}^{2}$ である。割れは介在物起点でマクロ的には $\{100\}$ 面上に あるが破面はへき開とは明らかに異なっていて, 明瞭で はないが約 $0.3 \mu \mathrm{m}$ 間隔の縞模様と, さらにその内部には 約 $30 \mathrm{~nm}$ の不規則な細かい縞がある. 破面全体としては 斑で丸みを帯びている。また，水素割れが伝播した領域 を透過電子顕微鏡で観察すると高い転位密度の列が生成 しており，微細な縞はすべり帯の生成に関連していると 考えられている.

ブリスターが $\{110\}$ に沿い＜110＞方向にジグザグに進 展し，ブリスター内面の転位密度が高いことは以前に純 鉄多結晶試料で報告されている99, 10)。重要な問題はこれ らの特徵が水素脆性, すなわち割れの早期の発生や成長 の助長とどう結びつくかである. 破壊過程については次 節で述べるが，とくに縞模様が疲労における突き出し (extrusion) や入り込み (intrusion) のようなすべりステ 


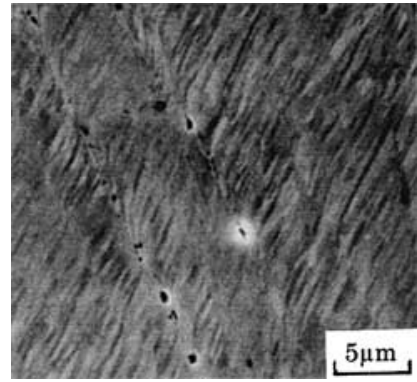

図 2 水素添加しながら引張り破断させた粗粒純鉄試料内部の 腐食組織（筋はすべり面のトレースに一致し，変形帯に 沿ってエッチピットや微小割れが生成している) ${ }^{11)}$

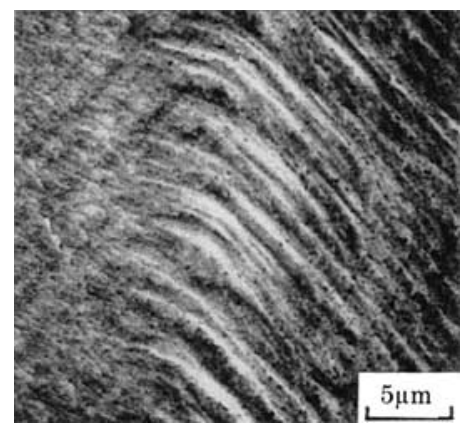

図 3 図 2 の変形帯の部分の拡大写真 ${ }^{11}$

ップなのか，あるいは図 1 のような微細空洞を伴うもの か，そしてそれが割れ進展の停止線としての役割なのか， 逆に割れを進展させる積極的な役割を持つのかが水素脆 性の本質として重要である。

南雲らは水素添加しながら $3 \times 10^{-5} / \mathrm{s}$ の歪み速度で引 張り破断させた純鉄粗粒多結晶及びバンブー構造単結晶 試料を引張り軸に平行に切断し, 断面を研磨・腐食して 顕微鏡観察を行った ${ }^{11)}$. 水素添加は $3 \% \mathrm{NaCl}$ 水溶液を用 い，電流密度 $0.1 \mathrm{~mA} / \mathrm{cm}^{2}$ の陰極電解の比較的弱い条件 で，破断までの変形量は大きい。いずれの試料でも図 211) に示すように粗い帯状とさらにその内部に層状の組 織が発達しており，その境界にエッチピットや微小ボイ ドが生成している。方位解析の結果，带状及び層状の筋 は $\{110\}$ 及び $\{112\}$ のすべり面のトレースと一致してお り，さらに筋模様の部分を拡大すると図 $3^{11)}$ のように帯 状境界では層状域が大きく屈曲している。筋がすべり面 のトレースと一致し，境界を挟んで結晶回転が起きてい ることから，筋の部分は主すべりが二次すべり系の活動 によって阻止された変形带であると考えられる。変形带 では多重すべり系の転位間相互作用が大きく，転位密度 が高い。実際に破面付近に転位セルが带状に形成されて いることが透過電子顕微鏡で観察されており，七ル壁は $\{112\}$ 面のトレースと一致している11).

この場合，破断は丸棒試料がくびれた後で起きている が，破面は大きな筋状になっており，これは図 $4^{111}$ に示 したように試料内部の帯状組織に連続している。組織が 腐食されやすく，エッチピットが生じることはそこの久 陷密度が高いことを意味しており，带境界に沿って微小 き裂が生成することも観察されている。このことは変形 帯に割れの起点となる微小ボイドが発生しやすく，主き

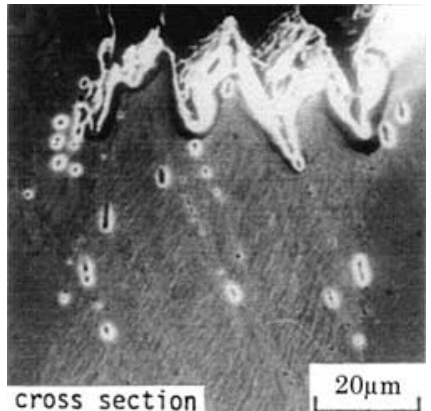

図 4 図 2 の試料の破面に表れた縞状模様と内部変形带の生じ たエッチピットとの対応 ${ }^{11}$

裂と連結すればその進展を容易にすることを示唆してい る。すべり帯内部に久陥が生じることは高い密度の転位 の相互作用によるもので，第 5 報12) 図 1 のトリチウムオ ートラジオグラフ ${ }^{13)}$ で示したように必ずしも水素の存在 を必要としない一般的な現象である。しかし，水素が欠 陷密度を増大させる機構があれば延性破壊的なモードの 脆化が助長されることになる。このことは次報の水素脆 性機構で詳しく述べる。

図 4 に見られるような破面のファセットが試料内部の すべり帯とつながっていることは, 水素添加して引張り 破断させたオーステナイト系ステンレス鋼 でも観察され ている ${ }^{14)}$ 。この場合の試料厚さは $20 \mu \mathrm{m}$ で水素添加は $0.5 \mathrm{M} \mathrm{H}_{2} \mathrm{SO}_{4}+0.25 \mathrm{~g} / \mathrm{L} \mathrm{NaAsO}_{2}$ 溶液を用いた陰極電解で 水素量は数 at \%から $10 \mathrm{at} \%$ 程度である. 割れはすべり帯 に沿って発生し，破面のステップはすべり帯の境界であ る。また，マクロ的には粒界に沿う割れであっても，破 面にはすべり帯の突き出しによるステップを伴っている こと, 水素量の増加に伴ってすべりの局所化が助長され ることを示している.

\subsection{3 ディンプル及び擬へき開破面}

延性破壊は通常ディンプル破面で特徵づけられ，比較 的大きな一次ディンプルとその中間領域に微細な二次デ インプルがある。ディンプルの周辺はせん断引裂き（tear ridge）である。デインプルは微細ボイドが成長して連結 したものであり，通常は第二相粒子が起点とされている。 実際に一次ディンプルの底には第二相粒子が観察される ことが多いが，二次ディンプルには異相を伴わないこと が多く，その成因や連結の過程が問題である。 3.1 節で 後述する。

多結晶フェライト鋼やマルテンサイト鋼で水素脆化が 小さい場合にはディンプルの痕跡が観察されることがあ る. Gordon らは下部ベイナイト組織の高純度ローター 鋼 $(0.25 \mathrm{C}, 3.70 \mathrm{Ni}, 1.70 \mathrm{Cr}, 0.40 \mathrm{Mo}, 0.12 \mathrm{~V}, 0.0015 \mathrm{~S} ; \mathrm{wt} \%)$ に斜め切欠きをつけた小型引張り (compact tension) 試 験を行い，水素予添加の影響を調べている15)。水素予添 加は $100^{\circ} \mathrm{C}$ の $13.8 \mathrm{MPa}$ 水素ガス中に 4 日間㧍き, 水素量 は 2 at.ppm である. 破面はディンプルであるが，水素添 加によって微細化し，せん断応力成分が増加するにつれ てディンプルの微細化とせん断的な変形及び全体の不規 則な平坦化が顕著になることが報告されている.

一方，擬へき開破面とは脆性破面に似た比較的平坦な 破面であるが，へき開面の破断ではなく，リバーパター ンとは異なる不規則な模様を持つ破面の総称である。マ 


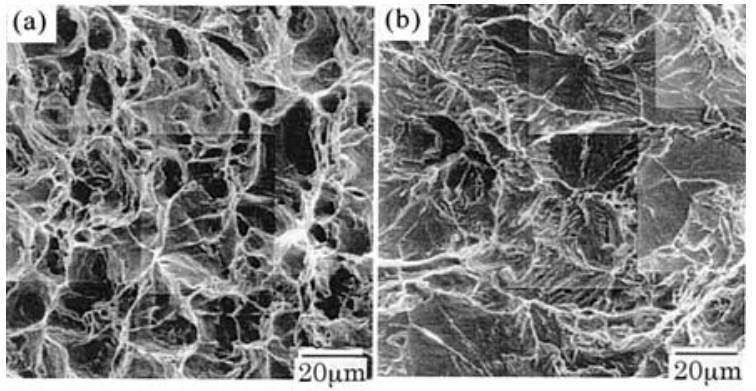

図 5 低炭素フェライト・パーライト鋼の水素添加（a）なし, （b）ありにおける 3 点曲げ試験の破面 ${ }^{16)}$

ルテンサイト鋼の水素脆性破面にしばしば観察され，水 素脆性破面の特徵の一つである。図 $5^{16)}$ は低炭素フェラ イト・パーライト鋼を水素予添加有無で 3 点曲げ試験で 破断させた試料の破面である。水素添加は $3 \% \mathrm{NaCl}+3$ $\mathrm{g} / l \mathrm{NH}_{4} \mathrm{SCN}$ 水溶液で電流密度は $0.5 \mathrm{~mA} / \mathrm{cm}^{2}$ で $24 \mathrm{~h}$ 行 っている. 水素添加しない場合はディンプル模様の延性 破面であるが，水素添加すると不規則な破面になり，注 意してみるとディンプルが平坦化してその境界が途切れ たようになっている。すなわち，この場合の擬へき開は 延性的な破壊でディンプルが発達せずにせん断変形で崩 れたものに近い。破面が平坦化することは割れ伝播に伴 うエネルギー消費が少ないことを意味している.

Morris らは疲労予き裂をつけた低炭素マルテンサイト 鋼 $(0.06 \mathrm{C}-5.86 \mathrm{Ni}-1.21 \mathrm{Mn}-0.69 \mathrm{Cr}-0.2 \mathrm{Mo}$, mass\%) に水素 予添加して 3 点曲げ試験を行い, 破面観察を行ってい る17). 水素添加は $\mathrm{As}_{2} \mathrm{O}_{3}$ と $\mathrm{CS}_{2}$ を加えた $1 \mathrm{~N} \mathrm{H}_{2} \mathrm{SO}_{4}$ を用 いた㓌極電解で, 電流密度は $100 \mathrm{~mA} / \mathrm{cm}^{2}$ で $24 \mathrm{~h}$ 行って いる．破面は $\{110\}$ 面に近く，マルテンサイトのラス構 造を残した不規則なフレーク状で擬へき開破面としてい る. 破面直下組織の透過電子顕微鏡観察から, 破面は $\{110\}$ 面に近いマルテンサイトのラス境界に沿っていて， 破面近傍の塑性歪みも大きく破面下に微細割れも生成し ていることが観察されている。擬へき開破面は一定の特 徵を持つものではないが，マルテンサイトラス境界も転 位セル壁も $\{110\}$ 面に近い転位密度の高い領域という点 で共通している.

\section{2 粒界破壊}

高強度鋼の水素脆性破面にはしばしば結晶粒単位の平 坦な形状を示す破面が観察され，粒界破壊と呼ばれる。 このような破面は水素脆性に特有ではなく, マルテンサ イト鋼の焼戻し脆性などでもよく知られている。焼戻し 脆性では例えば延性・脆性遷移温度が $\mathrm{P} ， \mathrm{As} ＼textrm{S b}$ などの 粒界不純物濃度の増加に伴って上昇し, 不純物偏析が粒 界結合力を低下させるとされている．焼戻し脆化が水素 脆化を助長することは HY 130 鋼（ $0.1 \mathrm{C}-5 \mathrm{Ni}-0.5 \mathrm{Cr}-$ $0.5 \mathrm{Mo}^{-0} 0.1 \mathrm{~V}$, mass \%) について吉野らが示している ${ }^{18)}$. 試験は疲労ノッチを入れた片持ち 3 点曲げ試験で $\mathrm{As}_{2} \mathrm{O}_{5}$ を添加した $0.1 \mathrm{~N} \mathrm{H}_{2} \mathrm{SO}_{4}$ 中で定荷重遅れ破壊をさせてい る. 焼戻し脆化処理した試料では割れ発生の限界応力拡 大係数が顕著に低下する. 破面を脆化処理の有無で比較 すると，脆化処理しない場合にはき裂進展開始は粒界破 壊であるがすぐにへき開破壊と延性破壊の混合となり，
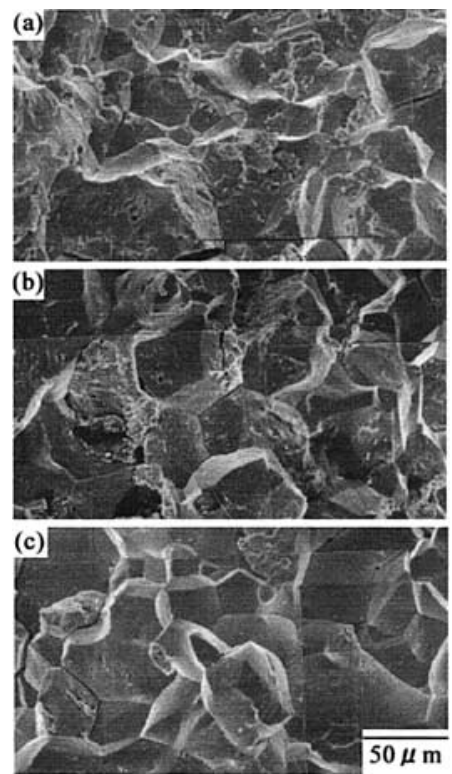

図 $6 \mathrm{Mn}$ 量を変えたマルテンサイト鋼の水素脆性破面 ${ }^{20)}$ Mn 量 : (a) 0.5 , (b) $1.0, \quad$ (c) 1.5 mass $\%{ }^{20}$

最後はへき開で急速進展する。一方，脆化処理材は全面 が粒界破面になる。

しかし，破面が結晶粒の形状を残すことは必ずしも割 れが粒界結合の破断によるとは限らないことに注意が必 要である。水素脆性ではないが, 高強度 7075Al 合金の破 壊勒性試験で $\mathrm{Mg}$ や $\mathrm{Zn}$ の添加量を増やして高強度化し た材料はマクロ的には粒界破壊するようになる ${ }^{19)}$ 。この 場合，破面には粗いすべり帯のトレースがあり，0.1 $\mu \mathrm{m}$ 程度の浅い微細ディンプルが $\eta$ 析出物を起点として観察 されている。そして粒界近傍には $30 \mathrm{~nm}$ 程度の幅の析出 物がない層がある。これらの特徴から無析出層の強度低 下が粒界に沿う歪み集中を起こし，延性破壊的に粒界に 沿う破壊になるとしている。

水素脆性との関係では, 図 $6^{20)}$ に Mn 量を変えた 0.3 mass \% C マルテンサイト鋼に水素添加しながら低歪み速 度で引張り破断させたときの破面を示した。水素添加は $\mathrm{NH}_{4} \mathrm{SCN}$ を添加した $3 \% \mathrm{NaCl}$ 水溶液中で $0.5 \mathrm{~mA} / \mathrm{cm}^{2}$ の 電流密度による陰極電解である。全体としては粒界破面 であるが不規則でちぎれたようなこまかい筋状パターン (tear ridge) があり, Mn 量が増加するとそれが少なくな って平滑化してくる. 走査型レーザー顕微鏡で測定した 破面表面の平均粗さを図 $7^{20)}$ に示した。引裂き状のパ夕 ーンは大きな塑性変形が起きていることを意味してい る. $0.5 \% \mathrm{Mn}$ 鋼の破面を化学腐食して破面と組織の対応 を調べると tear ridge はマルテンサイトのラス界面にあ る.すなわち，ラス境界の転位密度が高まり，それに伴 って割れが進展することを示唆しており，擬へき開や縞 状破面の生成と共通している。

水素脆性との関係で見れば破面が平坦化することは割 れの進展抵抗が少なくなることを意味し, 実際に破断応 力や破断伸び，あるいは断面減少率で評価した水素脆化 度は $\mathrm{Mn}$ 量の増加に伴って増大する。そして重要なのは 一定の塑性歪みを与えたときの水素吸蔵量, すなわち水 素をトラップする欠陥密度が Mn 量が増加すると増大す 


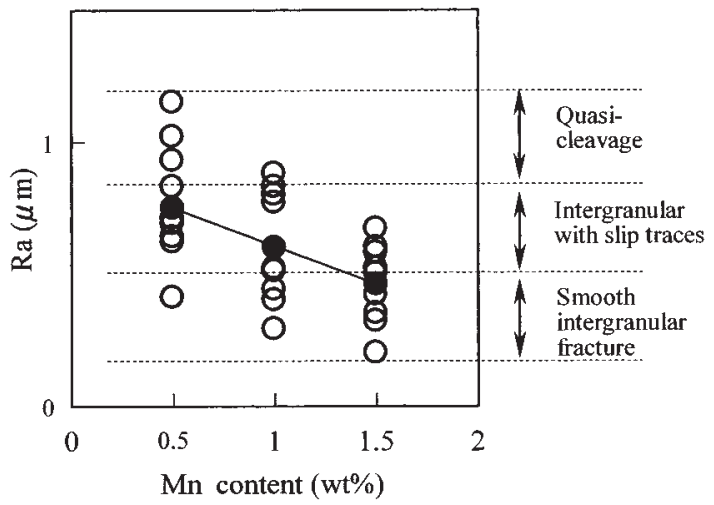

図 7 走査型レーザー顕微鏡で測定した図 6 の破面平均粗さ Ra. と破面形態との関倸20)

ることである ${ }^{20)}$ 。これは粒界破壊であっても粒界近傍の 局所的な塑性変形とそれに伴う欠陥生成を伴っていて, その程度が水素脆化度と関係あることを示唆している*1.

図 6 の試料で旧オーステナイト粒界に炭化物が電子顕 微鏡で観察されるが, Mn 量に伴う粒界性状の違いは明 確にはなっていない。一方，焼戻し脆性における粒界へ の不純物偏析は粒界割れを伴う水素脆化を増大させる が，BN などの粒界微細析出物があると水素脆化がさら に増大することが報告されている ${ }^{21)}$ 。これらの結果は, 粒界割れが単に水素による粒界結合力の低下によるもの ではなく，粒界近傍における転位すべりが割れの生成と 成長に本質的な役割を果たしていると考えられるが，水 素脆性機構で後述する.

\section{3 破面形態の応力依存性}

破面形態は破断試料の全面で均一とは限らず，応力条 件や水素濃度の影響を受けるので材料の特徴づけには注 意が必要である. Beachem は高強度マルテンサイト鋼の 応力腐食割れ (SCC) 及び水素割れ破面形態の応力拡大係 数に伴う変化を報告している ${ }^{23)}$. 試料は切欠きをつけた AISI 4300 鋼（0.15 または $0.15 \mathrm{C}, 1.7 \mathrm{Mn}, 0.7 \mathrm{Cr}, 0.3 \mathrm{Mo}$, mass\%) で，切久きに楔を入れて小さなき裂を発生 (pop-in) させ, $\mathrm{SCC}$ は $3.5 \% \mathrm{NaCl}$ 水溶液に浸漬, 水素割 れは試料を $\mathrm{Mg}$ 陽極に接触させて, き裂の進展に伴う破 面の変化を 2 段レプリカ法による電子顕微鏡観察で調べ ている。

この試験法ではき裂の進展に伴って応力拡大係数は低 下し，SCCではき裂の進展は途中で停止する. Pop-in し たき裂は最初ディンプル状の延性破面で進み，擬へき開 になった後粒界破面を呈するという一般的な傾向があ り, SCCでも水素割れでも共通している。ディンプルや 擬へき開あるいは粒界破面上の tear ridge は破壊が塑性 変形を伴っていることを表しているが，Beachem はそれ ぞれの破面形態は大気中破壊と同じであり，水素の存在 による特徵的な違いは認められないとしている.また水 素量の測定はないが，水素が塑性変形を助長するという

*1この場合水素脆化は水素を添加しながらの引張り試験で評価してい る. したがって試験中の水素吸収があるので破断時の水素量は予歪 み試料の水素吸蔵量とは異なる。しかし, 粒界水素濃度が一定の場 合でも水素脆化感受性は塑性歪み誘起空孔量に伴って増加する ${ }^{22)}$.
考えから, 応力拡大係数が一定の場合にはき裂先端領域 の水素濃度が増加するにつれて粒界 $\rightarrow$ 擬へき開 $\rightarrow$ ディン プル破面になると推定している.

なお，水素脆性の破壊形態については寺崎らの解説が ある24).

\section{3. 水素脆性の破壊過程}

\section{1 延性破壊の基本事項}

脆性破壊の理論は材料の破壊特性の評価法に直結して 破壊力学として展開されており, 教科書も多(4), 25)。一 方，延性破壊は比較的徐々に進行するので，試料全体の 破断に脆性破壊における Griffith 条件のようなクライテ リアや critical な事象がそしく，またミクロ的な実体や支 配要因の体系化も不足している。しかし, 破壊形態でみ たように, 水素脆性には延性破壊的な性格が強い. そこ で水素による特徴を見る前に，まず延性破壊の主な事項 を要約しておく.

延性破壊を特徵づけるのはディンプル破面であり，そ れは微細ボイドの発生と成長・連結を表している。ディ ンプルの起点としてょく知られているのは第二相粒子 で，材料の破断伸びや断面減少率が比較的大きい第二相 粒子の量の影響を強く受けることはよく知られている. 粒子の界面剥離あるいは粒子自体の割れを作るのは塑性 歪みあるいは応力である。したがって，延性破壊は歪み や応力が集中する領域で発生しやすい。 また，支配して いる応力や歪み成分が引張りかせん断かによって，ディ ンプル形状は等軸か伸張型かになる.

一方，第二相粒子を伴わないディンプル生成も実際に 観察されている。 van Stone ら ${ }^{26)}$ は $\alpha \mathrm{Ti}$ 合金の低温にお ける破壊でせん断変形帯がぶつかる粒界や双晶境界に微 細ボイドが生成すること, Wilsdorf ら ${ }^{27)}$ は電子顕微鏡に よる動的観察で $\mathrm{Ag}$ 単結晶試料のき裂先端に結晶学的な 特徴を持つ微細ボイドが連続して生成することを見い出 している.また，純鉄単結晶試料でき裂先端の塑性歪み が大きくなって転位セルが生成するとき，七ル間の方位 関係からセル壁に微小ボイドが生成していると結論して いる ${ }^{28)}$. 理論的には Cuitiňo と Ortiz は塑性変形で生成す る原子空孔の凝集によって延性破壊に導く微小ボイドが 形成することを導いている ${ }^{29)}$ 。このボイド生成機構は高 純度材料以外では異相粒子に起因する機構に比べて通常 はマイナーな作用である場合が多いが，空孔生成が容易 になるような状況では破壊に支配的になり得ることに注 意すべきである。

いったん生成した微小ボイドは塑性変形の進行に伴っ て成長する。その要因にはボイド表面からの，あるいは 表面へのすべりがあるが 3 軸応力の寄与が大きい. 実際 に同一歪み量におけるボイドの断面積は切欠きつき試料 の方が平滑試料よりも大きく30)，3 軸応力の効果と考え られる。また，ボイドの成長のほかにボイドが合体して 大きくなる効果もあり, McClintock は塑性力学計算でボ イドの成長を求め, ボイドの接触・合体による破壊条件 を示している ${ }^{31)}$. 3 軸応力の存在によってボイド成長が 助長され, とくに加工硬化指数が小さいと顕著になる.

ボイドの連結にはさらに離れたボイドが帯状のボイド シートによって連結する機構があり，実際に $\mathrm{Cu}^{32)}$ 及び 


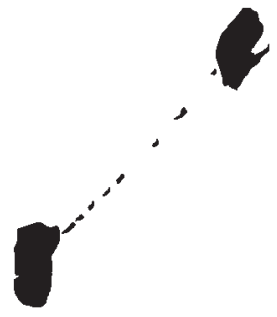

図 8 介在物に生成したボイドを連結する最大せん断応力面に 沿うボイドシートの模式図

AISI 4340 鋼33) で観察されている. 図 8 がその模式図で, 大きい介在物に生成したボイドから最大せん断応力面に そってせん断変形帯が出来るが，そこに微小ボイドがシ 一ト状に生成して大きなボイドを連結する，第二相粒子 から生成する一次ディンプルの数が少ない場合にはこの 機構がボイド連結に支配的になる。

一方, 隣接するボイドの中間領域が塑性不安定化して 連結する機構が内部くびれ（internal necking）として Thomasonによって示されている34),35). 不安定条件は試 料内部に蓄えられる，あるいは消費されるエネルギーよ りも外力がなす仕事が大きくなることで, 塑性力学によ る計算が同じ大きさのボイドを規則的に配置した剛塑性 体モデルについて行われている．加工硬化は取り入れて いない. 3 軸応力が大きくなると破断歪みが低下するこ とは McClintockの結果と共通しており，ボイドの配列 としては中間の領域が細長くなると不安定化しやすくな る.これは隣接して平行に並んだボイドの連結機構であ り, 図 8 のような強いせん断変形带に生成したボイドシ ートによる連結とは別である。

大小の第二相粒子があるときに，き裂先端からの歪み の局所化とそれに伴うボイドの生成・連結は Needleman と Tvergaardによって示されている ${ }^{36)}$. 計算法は弾・粘 塑性体の有限要素法解析 (FEM) で, モデルとしては大 きな粒子をき裂の周囲に規則正しく配列させ, 小さな粒 子はその中間に存在させる. 変形の進行に伴って大きな 粒子からは局所応力で, 小さな粒子からは局所歪みで支 配されてボイドが発生するとし，き裂先端の要素のボイ ド体積率がある限界を超えるとき裂の進展が起きるとす る。ここで小さな粒子は体積率とボイド発生の限界歪み で特徴づけられているので，このモデルでは必ずしもボ イド起点として粒子を想定する必要はない。計算では鈍 化するき裂先端から歪みが局所化し, き裂が進展する過 程が示されている. Needleman らはまた 3 軸応力の分布 も計算しているが，延性き裂の進展は 3 軸応力では支配 されていない。これを水素脆性に応用した解析は後で 3.3, 3.4.3 項で述べる.

なお，ディンプル型破壊のミクロ的な様相については 文献 30）が総説である.

\section{$3.2 \mathrm{R}$ 曲 線}

材料の破壊特性は破壊時における応力や伸び，あるい は応力拡大係数などの勒性值で表現されることが多い. 水素脆性でも同様であるが，それらの值は結果であって そこに至る過程は別な問題である。また破面は割れが進 展した経路を示すが材料内部の変化は直接的にはわから

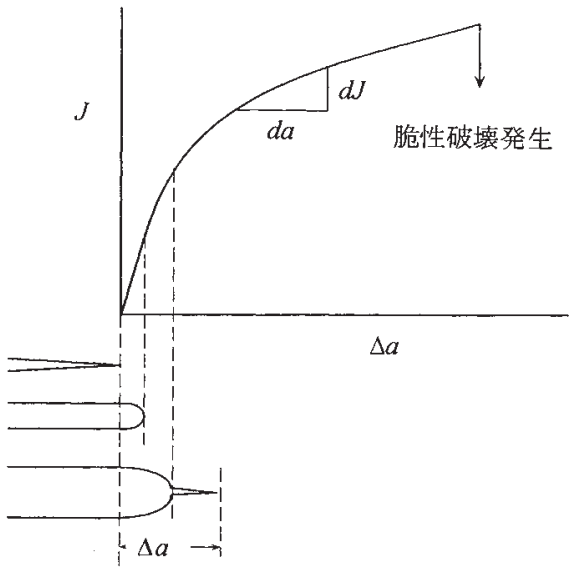

図 9 延性・脆性破壊遷移温度域における $\mathrm{R}$ 曲線と割れ進展の 模式図

ない。そこでR曲線 (resistance curve) 25), 37), 38) を用いて 割れの発生や成長, 最終破断過程の負荷状態を順を追っ て求めることが出来る。これは予き裂をつけた試料のき 裂進展量とそれに対応する $J$ 積分值とをプロットしたも ので, 延性・脆性破壊遷移温度域における形をき裂の模 式的な形と合わせて図 9 に示した。遷移温度域では応力 の増加に伴ってまず予き裂の先端が鈍化した後で新たに 延性き裂が発生し，それが安定的に成長して不安定破壊 になり急速破断する.

$J$ 積分は材料の勒性を表す量の一つで, 非線形挙動を 示す物体のき裂進展に伴う歪みエネルギー開放率の拡張 として

$$
J=\int_{\Gamma}\left[W d y-T \frac{\partial u}{\partial x} d s\right]
$$

で定義される ${ }^{25)}$, 39), 40)．積分はき裂先端を囲むようにき裂

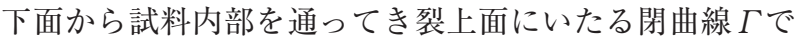
行い, $T$ は線要素 $d s$ 部分での応力ベクトル, $u$ は変位べ クトル， $W$ は歪みエネルギー密度である. $J$ 積分值は $\Gamma$ のとり方によらないのが特徴で, き裂先端に塑性域が生 成している場合に，そこを过回して弾性計算で求められ るという利点がある。逆に，き裂近傍の応力・歪み場を $J$ 積分值をパラメーターとして表すことが出来る.

$J$ 積分の物理的な意味はき裂が進展するときの試料の ポテンシャルエネルギーUの変化率,

$$
J=-d U / d a
$$

で, 線形弾性体では歪みエネルギー解放率 (strain energy release rate) $G$ や応力拡大係数 (stress intensity factor) $K$ などの破壊勒性パラメーターと (3) 式のように関 係づけられる。

$$
\begin{aligned}
J=G & =K^{2} / E & & \text { (平面応力) } \\
& =\left(1-v^{2}\right) K^{2} / E & & \text { (平面ひずみ) }
\end{aligned}
$$

$E$ はヤング率， $v$ はポアッソン比である.したがって， $\mathrm{R}$ 曲線は $J$ 積分值の代わりに $K$ 值やき裂開口変位を用い ても類似の形になる.

(1) 式は例えば有限要素法で局所応力・歪み場が計算 出来れば求められるが, 実験的には荷重〜荷重点変位の プロットから，

$$
J=\frac{2 A}{b B}
$$



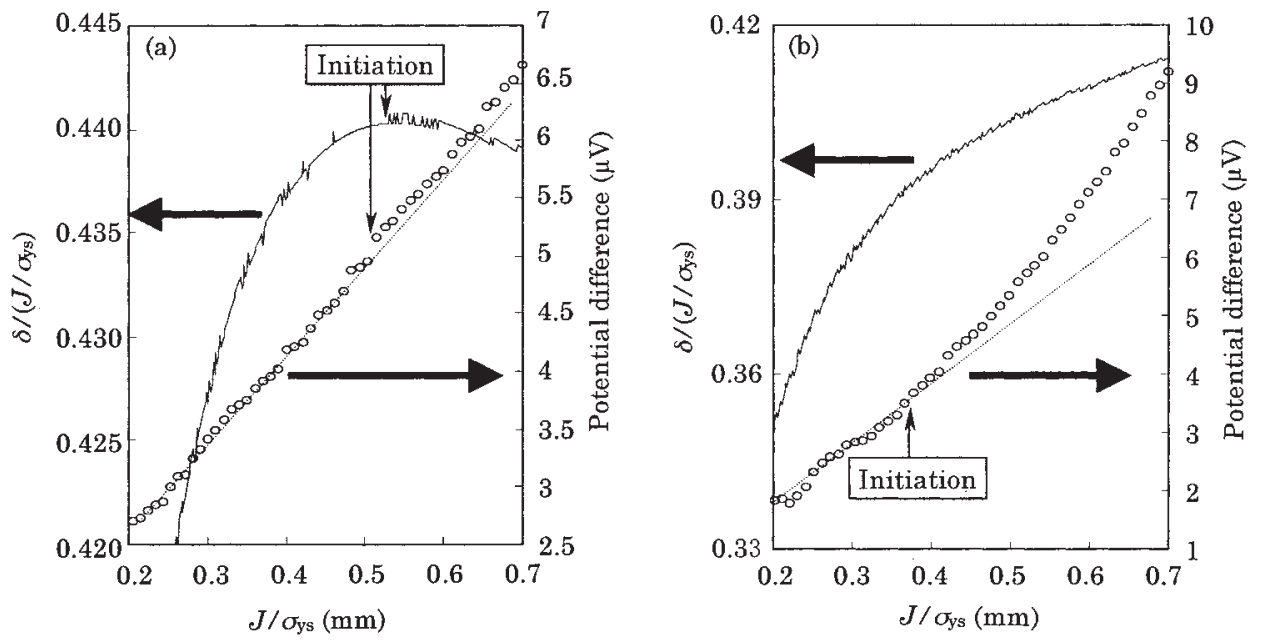

図 10 低炭素フェライト鋼の 3 点曲げ試験に扔けるき裂進展に伴うき裂開口変位 $(\delta)$ とき裂先端リガメントの電気抵抗变化 ${ }^{16)}$ （a）水素添加なし，（b）水素添加ありの場合

で簡便に求められる ${ }^{41)}$. $A$ は荷重〜荷重点変位曲線下の 面積， $b$ は試験片のリガメント長さ， $B$ は試験片厚さで ある。

$\mathrm{R}$ 曲線の終端は脆性破壊，あるいは不安定延性破壊の 発生であり， R 曲線の勾配は試験温度でほとんど変わら ない42) ので破壊勒性の温度依存性は不安定破壊の発生で 支配される。不安定破壊発生後の消費エネルギーは小さ いから, 破壊勒性は不安定破壊の発生と, それまでに費 やされるエネルギーで決まることになる。したがって， 破壊勒性の支配過程としては延性き裂の発生とその伝播 抵抗，それに不安定破壊の発生が問題になる*2.

\section{3 安定延性き裂の発生}

$\mathrm{R}$ 曲線に戻って破壊過程における水素の影響を調べる ことにする。予き裂から新しく延性き裂が発生するとき の $J$ 積分值が $J_{\mathrm{IC}}$ であるが， R 曲線上でそれを明確に判定 することは難しい場合が多い。延性き裂の発生は予き裂 がその先端領域に生成した微小ボイドと連結することで 起きる. Needleman と Tvergaard は延性き裂が発生する ときにき裂先端開口変位 (CTOD) $\delta$ と $J$ 積分との比例関 係に小さな “jog”が表れることを有限要素法解析から理 論的に予測している ${ }^{36)}$. ジョグは極めて小さいが，藤井

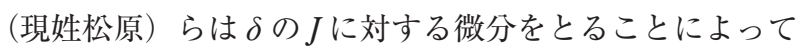
ジョグを顕在化することに成功した ${ }^{43)}$.

この手法を用いて下村と南雲は水素添加した低炭素フ エライト・パーライト鋼について延性き裂発生の検出を 行った ${ }^{16)}$. 試験は切欠きつき試料の 3 点曲げ試験で, 水

*2 き裂進展の不安定性は引裂き剛性率 (tearing modulus) $T_{\mathrm{R}}$,

$$
T_{\mathrm{R}} \equiv \frac{E}{\sigma_{y}^{2}} \cdot \frac{d J}{d a}
$$

で議論されている ${ }^{25), 37)}$. ( $E$ : ヤング率) $J$ の増加によってき裂の進 展が起こると荷重の低下があるが, それは試験片変位に占める弾性 変位の減少を伴う. 不安定条件はこの弾性変位の減少がき裂進展に 伴う塑性変位の増加を上回るとして与えられ, 中心き裂を持つ長さ $L$, 幅 $W$ の試験片の引張りでは $T_{\mathrm{R}} \leq 2 L / W$

と導かれる. したがって，不安定破壊の開始は必ずしも脆性き裂の 発生ではない。
素予添加を $3 \% \mathrm{NaCl}+3 \mathrm{~g} / \mathrm{L} \mathrm{NH}_{4} \mathrm{SCN}$ 水溶液を用いた陰 極電解で $0.5 \mathrm{~mA} / \mathrm{cm}^{2}$ の電流密度で $24 \mathrm{~h}$ 行なっている. き裂先端開口変位 $\delta$ と $J$ 積分の測定のほかに，き裂進展 をリガメント長さの減少に伴う電気抵抗の増加から検出 している. 図 1016) はその結果で, $J$ 積分は降伏強さ $\sigma_{\mathrm{ys}}$ で規格化し， $\delta$ は $J / \sigma_{\mathrm{ys}}$ の比をとっている。電気抵抗で 検出された延性き裂発生は水素予添加によって早期に起

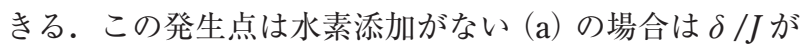
最大となる $J$ 積分值とほぼ一致し, 藤井らの結果 ${ }^{43)}$ を再 現している. しかし，水素添加された試料（b)では $\delta / J$ に最大值が表れないのが特徴である.

き裂開口変位 $\delta$ と $J$ 積分との比例関係にジョグが表れ る理由は，予き裂が先端域に生成した微小ボイドと連結 するときに $\delta$ が不連続的に増大するためである。したが って, 水素が存在するときにジョグが表れないのは，小 さなジョグが連続的に生成するためと考えてよい. Needleman らの理論予測36) は大小の介在物が存在する場 合にすべりの局所化によってマクロなせん断帯が発生し てボイドシートが形成されること, そして鈍化した予き 裂先端の要素中のボイド体積率が限界值に達したときに 応力伝達能 “stress carrying capacity” が消失するとした モデルに基づいている.したがって，“stress carrying capacity”が連続的に失われれば微小ジョグもまた連続 的に生成することになる。 Needlemann らのモデルでは 介在物を微小ボイド源としているが，ボイド生成は Cuitin̆o と Ortiz が示した ${ }^{29)}$ ように原子空孔の凝集であっ てもよい，そのときに水素の存在が欠陥生成を容易にす れば， $\delta$ すなわち $J$ 積分值が小さい段階で延性き裂の進 展が連続的に開始することになる。

なお，次項で述べるき裂進展を含めて比較的延性のあ る材料の破壊勒性については Ritchie と Thompsonの総 説44) がある。

\section{4 延性き裂伝播抵抗}

\subsection{1延性き裂進展抵抗の支配因子}

$\mathrm{R}$ 曲線はき裂が進展する際のき裂進展力の変化, 言い 換えれば延性き裂進展抵抗を表す。八木らは低炭素フェ 


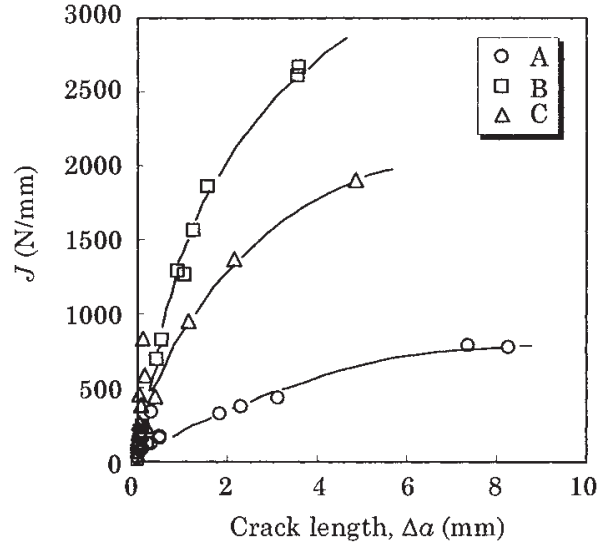

図 11 粒界炭化物量が異なる低炭素フェライト・パーライト鋼 の 3 点曲げ試験による R 曲線 45), 46)

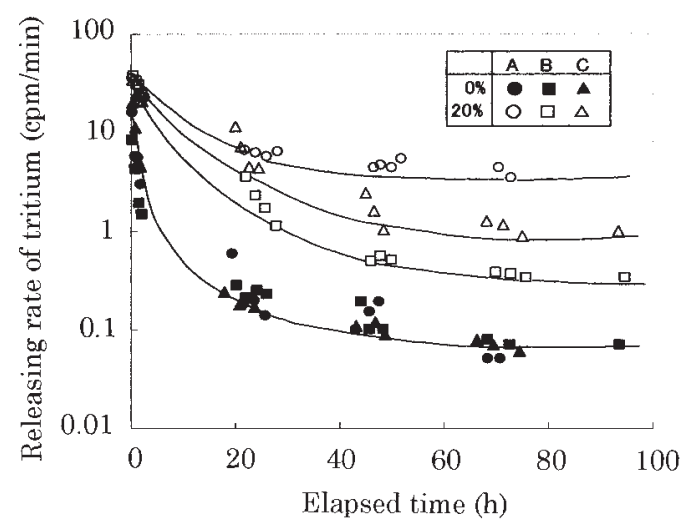

図 12 図 11 の鋼で未変形及び室温で $20 \%$ 引張り変形材に添加 したトリチウムの室温放出特性 ${ }^{46)}$

ライト・パーライト鋼の 3 点曲げ試験から $\mathrm{R}$ 曲線を求 め, き裂進展抵抗を支配する因子を調べている ${ }^{45)}$. $J$ 積 分はそれ自体がき裂進展抵抗を意味するが, そのき裂進 展に伴う変化をみるためにさらに $\mathrm{R}$ 曲線の勾配, $d J / d a$ をとっている， $a$ はき裂長さである. 図 1145),46) は 3 点曲 げ試験で求めた粒界炭化物の量が異なる 3 種の鋼の $\mathrm{R}$ 曲 線で, 炭化物量の増加に伴って延性き裂進展抵抗が低下 している. 3 種の鋼は Mn と Ni の添加量比率を変えたも ので粒界炭化物以外の組織や強度はほぼ同じである。炭 化物量を粒界すべり拘束率 $\eta$, すなわち炭化物が占めて いる粒界長さの全粒界長さに対する比率で表すと， $\eta$ の 值は鋼 A，B，Cでそれぞれ 58.1，33.2，43.5\%である. 粒界炭化物はすべりが粒界を越えて伝播することの障害 となり，転位の多重すべりを誘起して粒界近傍に転位の 相互作用に起因する多数の格子欠陥を生成すると考えら れる。

そこで塑性歪みを与えた試料に欠陥検出のプローブと して水素（ここではトリチウム）を添加し，その室温放 出特性を測定した結果が図 1246) である. 未変形材では鋼 による差はないが， $20{ }^{\circ} \mathrm{C} て ゙ ~ 20 \% の$ 塑性歪みを与えると拘 束率が大きいほど拡散性及び残存吸蔵水素量が増える。 これはすべり拘束が多いと塑性変形に伴って水素をトラ ップする欠陥が多く生成することを意味している．また， 図 $13^{46)}$ は変形温度を変えて $20 \%$ 歪みを与えた試料に

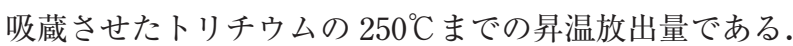

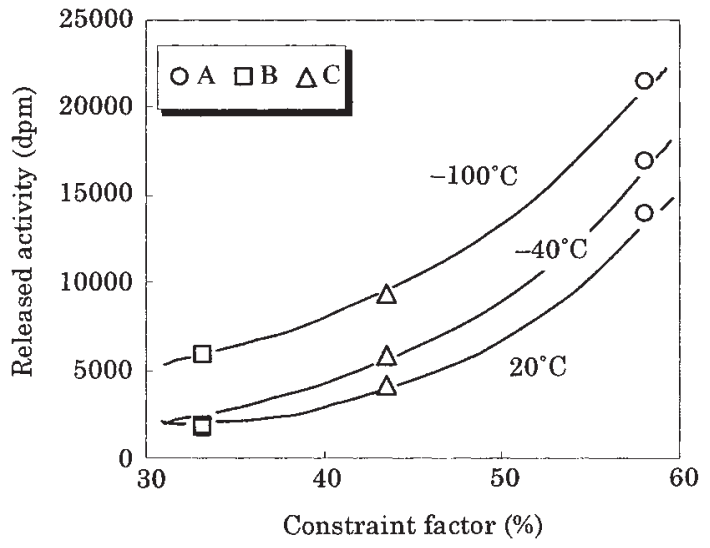

図 13 いろいろな温度で $20 \%$ の張り歪みを与えた試料に添加 したトリチウムの昇温放出量 ${ }^{46)}$

やはりすべり拘束率の増加に伴って水素吸蔵量が増加 し，また同一歪み量であっても変形温度が低いと欠陥生 成が助長される。このことは欠陥の実体は歪み量に対応 して密度が決まる転位そのものではなく，転位のすべり 挙動に伴って二次的に生成されることを示唆している. また, 昇温放出水素の内容は室温で容易に放出される拡 散性水素と, 強くトラップされた非拡散性水素の一部か ら構成されている。すなわち生成された欠陥は 1 種類で はないが，この場合は塑性歪みで増加する吸蔵水素の内 訳は前者の比率がずっと大きいことも示されている.

さきに述べたように47), 塑性変形に伴って拡散性水素 のトラップとなる格子欠陥が生成するが，その多くは変 形させた試料を $200^{\circ} \mathrm{C}$ 程度の低温で焼なますと消滅して しまうことが確認されており, 原子空孔性の点欠陷と考 えられる。そこで粒界炭化物量に伴う図 11 のき裂伝播 抵抗と図 12,13 の塑性誘起欠陥量とを対応させると, き 裂進展抵抗を低下させているのは塑性変形に伴って生成 する空孔性欠陥が多くなるためと考えられ，これはさき に述べた延性破壊のミクロ的な様相と一致する。

\subsection{2 欠㛊生成に伴う $\mathrm{R}$ 曲線の変化一有限要素法によ る解析}

き裂先端には塑性歪みの集中があり，そこでの欠陥生 成がき裂の成長を容易にするという考えは，さきに述べ たき裂先端の微小領域でボイド体積率が増加すると “stress carrying capacity” が低下するという Needleman らのモデル ${ }^{36)}$ に対応する．R曲線の形はき裂進展に伴う $J$ 積分值が求められれば理論的に計算出来る。そのため にはき裂先端の応力・歪み場を知ることが必要である が, 例えばFEM で求められる.

$J$ 積分はその定義の (1) 式からわかるように，連続体力 学でき裂先端領域における応力と歪み場で決まる量であ る.しかし, 図 11 に示した材料はマクロな変形応力が ほぼ同じなので計算には欠陷量の効果を取り入れなけれ ばならない. 組織中に微小ボイドがある場合の応力・歪 み場の FEM 計算法として Gurson のモデルがある ${ }^{48)}{ }^{49)}$. これは FEM でメッシュ要素の降伏関数 $F$ にボイド体積 率を取り入れて

$$
\begin{aligned}
F\left(\sigma_{\mathrm{ij}}, \sigma_{\mathrm{y}}, f\right) & =\frac{3}{2} \frac{\sigma_{\mathrm{ij}}^{\prime} \sigma_{\mathrm{ij}}^{\prime}}{\sigma_{\mathrm{y}}{ }^{2}}+2 f q_{1} \cosh \left[\frac{3 q_{2} \sigma_{\mathrm{m}}}{2 \sigma_{\mathrm{y}}}\right]-\left(1+q_{3} f^{2}\right) \\
& =0
\end{aligned}
$$




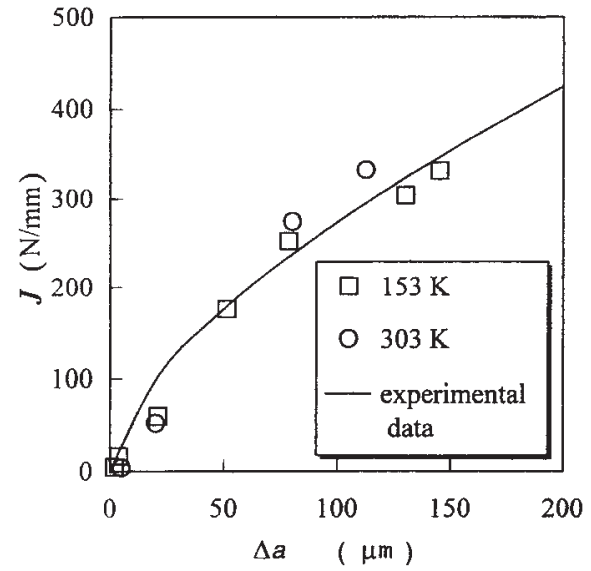

図 14 図 11 の $\mathrm{B}$ 鋼で $\mathrm{R}$ 曲線の実測值と FEM による計算值と の比較 ${ }^{50)}$ (試験温度を $153 \mathrm{~K}$ と $303 \mathrm{~K}$ にとっている)

としたもので，ボイドが存在すると要素の降伏応力が低 下する．ここで $f$ はボイド体積率， $\sigma_{\mathrm{y}}$ は降伏応力， $\sigma_{\mathrm{i} j}$, $\sigma^{\prime}{ }_{\mathrm{i} j}$ 及び $\sigma_{\mathrm{m}}$ はそれぞれ応力テンソル成分, 偏差応力テ ンソル成分, 静水応力である ${ }^{49)}$. (5) 式からボイドが存在 すると要素の降伏応力が低下することがわかる．ボイド 体積率 $f$ は歪み増加に伴って増加する．上記の Needleman らの理論 ${ }^{36)}$ はこの Gurson モデルをもとにしてい る.

吉田らはこの方法を用いて $J$ 積分を計算し，八木らが 求めた R 曲線を再現することに成功した50). 計算にあた っては破面解析及び組織観察から実測した微小ボイド体 積率と, 引張試験から求めた降伏応力や歪み硬化特性を 用いている。図 $14^{50)}$ は実測された $\mathrm{R}$ 曲線とシミュレー ション曲線とを比較したもので, き裂進展量の小さい段 階であるが両者はよく一致している。試験温度が $153 \mathrm{~K}$ と $303 \mathrm{~K}$ の場合について，それぞれの温度で測定された 降伏応力を用いて R 曲線を計算しているが温度依存性は 表れず，これも実験結果42) と一致する。この理由はき裂 先端領域で変形応力と歪みの温度依存性がJ積分として は打ち消してしまうためであることが示されている.

塑性変形に伴って空孔が生成する機構は転位同士の動 的相互作用であるから，すべりが集中して転位密度の高 い領域で空孔生成も活発になることが予想される。結晶 粒界におけるすべり拘束は，転位の堆積と多重すべりを 介して粒界近傍にそのような領域を作る。図 4 の R 曲線 は「延性き裂進展抵抗はき裂先端域のボイド生成の容易 さで支配され，さらにボイド生成は塑性変形に伴う空孔 密度の増加でもたらされる」として理解される。また, き裂先端の歪みやボイドの二次元的な分布も Gurson モ デルによる FEM 計算から求められ, 要素中に初期微小 ボイドが存在すると，き裂先端の歪みやボイド生成の局 所化が助長されることが示されている50).このことは要 素の降伏関数だけではなくて幾何学的にもき裂の延性破 壊的な進展が容易になることを意味している.

\subsubsection{R 曲線に及ぼす水素の影響}

上記の結論は勒性に対する金属組織の機能として重要 であり，塑性変形に伴うボイド生成と容易になればき裂 進展抵抗が低下することになる。したがって，水素が塑 性変形に伴うボイド生成を容易にするのであれば， R 曲

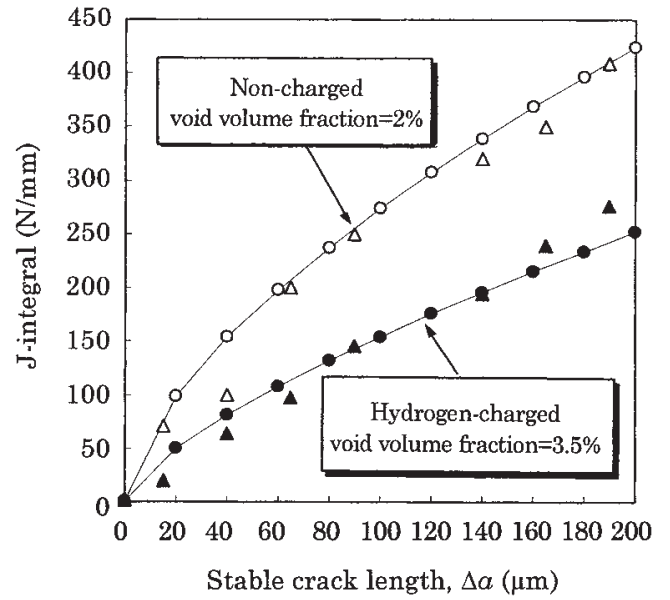

図 15 図 11 の $\mathrm{B}$ 鋼の水素添加有無に抢ける $\mathrm{R}$ 曲線の実測值と FEM 計算值の比較 ${ }^{51)}(\bigcirc, \bigcirc$ : 実測值， $\triangle, \boldsymbol{\Delta}$ : 計算値 $)$

線にその効果が表れることになる.

そこで，図 14 に示した低炭素 B 鋼試料に水素添加し, 同様な 3 点曲げ試験による $\mathrm{R}$ 曲線を示したのが図 1551) で ある. 断面が $10 \times 18 \mathrm{~mm}^{2}$ の切欠きつき試験片に図 10 と 同様に, $3 \% \mathrm{NaCl}+3 \mathrm{~g} / \mathrm{L} \mathrm{NH}_{4} \mathrm{SCN}$ 水溶液, $0.5 \mathrm{~mA} / \mathrm{cm}^{2}$ の電流密度 $24 \mathrm{~h}$ の陰極電解で水素予添加を行っている. 図にみられるように，水素添加によってき裂進展抵抗の 著しい低下が起きるが，この実測された R 曲線に及ぼす 水素の効果をシミュレーションで再現するには，核ボイ ドの体積率を $2.0 \%$ から $3.5 \%$ に増加させればよいことを 図 15 に同時に示してある。また図 $16^{51)}$ は同じく B 鋼の き裂先端での核ボイド分布を $2.0 \%$ と $3.5 \%$ の核ボイド体 積率で比較したものである。核ボイド体積率の増加に伴 ってき裂先端における局所化が進む.また引張り歪みの 局所化も進むがボイド密度で顕著である。

さきの図 14 では $\mathrm{R}$ 曲線のシミュレーションには実測 されたパラメーターを用いている。しかし，図 15 に示 した水素の効果の計算ではボイド体積率の值は実測 $\mathrm{R}$ 曲 線と一致するようにパラメーターとしてとっていて，そ の等価な実体は別に検討しなくてはならない。シミュレ ーションに用いた Gurson モデルはボイドの生成・連結 における Needleman らの理論 ${ }^{36)}$ のもとになっているも ので, 物理的にはき裂進展抵抗の低下はき裂先端の要素 の応力伝達能が低下することに帰着される. そして図 11 と図 13 との対応に見られるように, き裂進展抵抗の低 下は塑性変形に伴う久陷密度の増大と関係している。し たがって，定量的な表現は困難であるが，水素がき裂先 端領域における欠陷密度を増加させて応力伝達能を低下 させていると推定される。

実際に観察される破面形態は一次ディンプルの扁平 度, すなわち深さ $h$ と径 $w$ との比でみると, 水素添加に よってディンプルが浅くなっている.この特徵は欠陥密 度の高い領域がき裂先端に局所化することを水素が助長 することを示唆しており, FEM 計算で欠陥の二次元分 布を示した図 16 の結果と一致する.

応力腐食割れで進展するき裂先端が鋭くなっているこ とは，環境中疲労試験機に走査型原子間力顕微鏡 $(\mathrm{AFM})$ を設置したナノナノスコピックその場観察で確かめられてい 

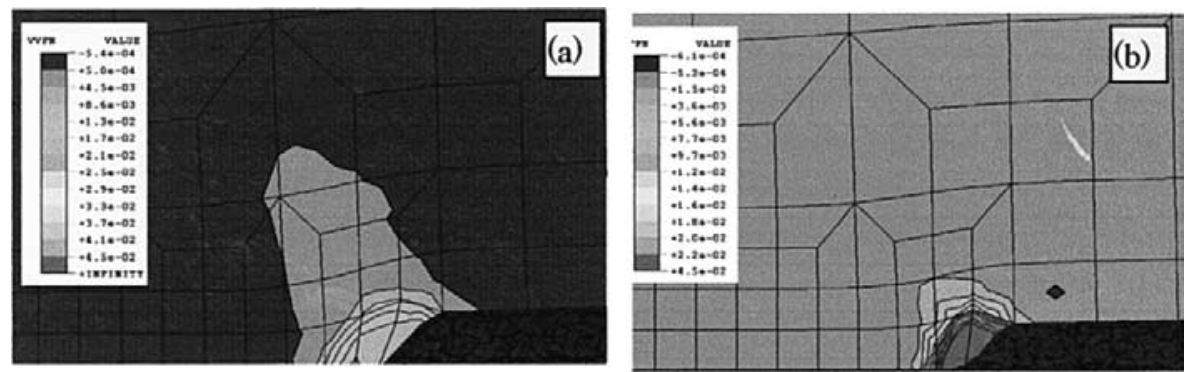

図 16 図 11 の B 鋼で水素添加（a）なし，(b) ありのき裂先端領域に抢ける核ボイド密度分布 ${ }^{51}$

る ${ }^{52)}$ ・試料は HSL180 鋼で環境は $21^{\circ} \mathrm{C}$ の $3.5 \% \mathrm{NaCl}+3$ $\mathrm{g} / \mathrm{L} \mathrm{NH}_{4} \mathrm{SCN}$ 水溶液である. 動的負荷条件で腐食環境で はき裂先端の開口变位 (CTOD) が乾燥空気中よりも鋭く なっている。

\section{4. 変形の局所化と塑性不安定性}

\section{1. 塑性不安定性}

材料の変形は実際には一様ではなく，局所的に進行す ることが多い。破壊現象ではその前駆段階として変形の 局所化が重要なことは言うまでもない。前節でみたよう に，ボイドの生成や成長・連結は局所応力や歪みで支配 されることが多く，破壊現象ではき裂発生や伝播の経路 になる変形の局所化が重要である。塑性変形の局所化が 進むと外部応力の増加を伴わずに変形が進行する，いわ ゆる塑性不安定性があり，引張り試験片のくびれ現象が よく知られている。一方，前節でみた延性破壊における ボイドシートの生成や 3.3 項で述べた応力伝達能の消失 も局所的な塑性不安定化の例で, 局所化は試料全体に起 きるとは限らない。切欠きは応力や歪みの局所化を起こ すが，これがミクロな塑性不安定性と割れ発生に進む例 としては切欠き底に特性すべり線に沿う割れの発生が観 察されており ${ }^{53)}{ }^{54)}$, 理論的にも FEM 解析から裏づけら れている。

塑性不安定性は力学的には変位勾配の不連続が生因で あり, 材料因子としては降伏応力の結晶方位依存性, 加 工硬化特性，すべり系，転位に働く表面力などのような 内質的因子と, 局所化のきっかけとなる表面切欠きや粗 さ，内部割れや第二相粒子，結晶粒界などの外質的因子, さらに変形条件として変形速度などいろいろな要因があ る55), 56). 引張り試験におけるくびれの発生が材料のマク 口な加工硬化特性で支配されることはよく知られている が，組織や試料の幾何学的形状の不均一性も塑性不安定 化のひとつの要因になる。塑性不安定性による破断には 必ずしも第二相粒子を必要としない。実際に時効硬化型 アルミニウム合金単結晶平滑試料の引張りで, 粗いすべ り帯が生成した後にその面上に大きなせん断すべりが発 生して破断することが観察されており ${ }^{57)}$, 割れの起点は 粗いすべり帯の根元である.

水素脆性では塑性不安定性における水素の役割が材料 特性によるせん断変形帯生成と，不均一性としてのボイ ド生成のどちらなのかは大きな問題である。そして実験 としては試料内部で水素析出による損傷がないかなど, 水素添加条件をよく吟味しなくてはならない。 なお，文 献 55）は高速変形，56）は水素による塑性不定性の集録
及び総説である。

\section{2 水素による塑性不安定性の助長}

水素脆性における延性き裂進展ではき裂先端の鈍化が 小さく破面は平坦で，これらの特徵は塑性域が局所化す る塑性不安定性が水素によって助長されることを示して いる. $\mathrm{H}_{2} \mathrm{~S}$ を含む環境で鋼中の伸長した $\mathrm{MnS}$ に割れが生 成し，それがせん断変形帯に沿って連結することがライ ンパイプなどで観察されているが，これは図 10 のボイ ドシート生成と同様な現象が水素によって塑性不安定性 が助長されているために起きるひとつの例であろう.

Park と Thompsonは炭化物を球状化した AISI 1520 鋼 (YS : $300 \mathrm{MPa}$ ) の丸棒試料（試験片直径 : $5 \mathrm{~mm}$ ) で 1 軸 引張り試験を行い, 水素添加材では試料中心部に生成し たクラックが図 10 のような引張り軸に $55^{\circ}$ 傾いたボイド シートで連結することを観察している ${ }^{58)}$ 。水素予添加は $1 \mathrm{~N} \mathrm{H}_{2} \mathrm{SO}_{4}+1 \mathrm{mg} / \mathrm{L} \mathrm{As}_{2} \mathrm{O}_{3}$ 溶液中 $1 \mathrm{~mA} / \mathrm{cm}^{2}$ の電流密度 で $24 \mathrm{~h}$ 行い， $\mathrm{Cu}$ めっきを施している. 水素添加だけで は不可逆的な損傷は起きていないことを確かめている。 水素添加で一様伸びは約 30\%低下するが，内部の割れの 観察から水素の影響はボイド成長の後期から破断過程に かけて顕著である，そこで，炭化物界面が先にせん断で 剥離することが水素が塑性不安定性を助長する要件であ るとしている．破面はディンプル形態である.

Park らはさらに同じ鋼の切欠き試料の曲げ試験を行っ ている59)。割れが切欠き底表面から特性すべり線に沿っ て発生することは水素添加の有無にかかわらず共通であ るが，水素添加材では割れの生成は曲げ対称軸の近くで 多く，さらに図 1754) の模式図のように切欠き底の試料内 部でも特性すべり線に沿って二次割れが多数観察されて いる。しかし，二次割れの生成が多いのは切欠き底真下 の曲げ対称軸の近くではない。 そして，水素添加材では 割れの成長方向はすべり線に沿うモード II から切欠き底 に直角の引張り型モード I に移る。

このように，水素添加による二次割れ発生が切欠き直 下の 3 軸応力最大サイトよりもすべり線に沿って多いこ とから，Park らは水素が割れ発生を助長するのは単純な 水素量支配ではなくて機構は不明ながら塑性不安定性の 促進作用があるとしている，一方，モード II のき裂進展 はそれだけでは説明出来ず， 3 軸応力を含めた引張り応 力の影響もあることを示唆している. 3 軸応力状態は水 素濃度の増加とともに微小ボイドの成長も促進するが, それらの作用の分離はなされていない。

破壊勒性は脆性破壊に有利なモード I の負荷条件で評 価されることが多いが，せん断変形が破壊に寄与する場 


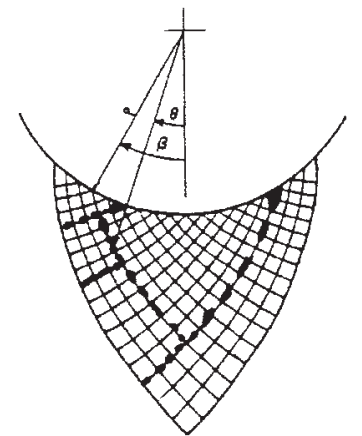

図 17 曲げ試験におけるU-切欠き 下領域で特性すべりに沿う割 れ発生の模式図 ${ }^{54}$

合にはモード III の負荷が加わると割れの発生が容易に なる. 水素脆性が脆性破壊的なのか延性破壊的なのかは, 負荷モードを変えたときの破壊勒性の違いを調べればよ い. そこで, Hirth らは小型引張り試験片の切欠き角度 を変えて混成負荷モードとし, R 曲線から延性き裂の発 生における水素の影響を調べている60), 61)。試料は $0.25 \mathrm{C}-$ $3.7 \mathrm{Ni}-1.7 \mathrm{Cr}-0.4 \mathrm{Mo}-0.12 \mathrm{~V}$ (mass\%) の焼戻し下部べイナ イト鋼（YS: $752 \mathrm{MPa}, \mathrm{TS}: 855 \mathrm{MPa}$ ) で, 水素添加は $100^{\circ} \mathrm{C}, 13.8 \mathrm{MPa}$ の $\mathrm{H}_{2}$ 䨌囲気で 4 日間保ち, $\mathrm{Cu}$ めっ で封じ込めている. 水素量は 2 at.ppm で, この水素量は 固溶水素としては室温では $1.26 \mathrm{GPa} の \mathrm{H}_{2}$ 䨌囲気に相当 する。

延性き裂が発生する $J$ 積分值, $J_{\mathrm{TC}}$, は水素添加材で低 下し，水素がき裂発生を促進することは明らかである. 切欠きを斜めにしてモード III 成分を増やすと水素によ る低下が大きくなり，450 の切欠き角度で水素添加によ る $J_{\mathrm{TC}}$ の低下は約 $30 \%$ になる。 $J_{\mathrm{TC}}$ をモード I 成分とモー ド III 成分に分けると, 混成モードによる $J_{\mathrm{TC}}$ の低下はモ ード III 成分が変化するためである．破面はディンプル 状であるが水素添加材のディンプルは小さく，モード III 成分の増加に伴ってさらに $1 \mu \mathrm{m}$ 以下に均一になってく る. FEM 解析からモード III 成分の増加によって切欠き 先端のせん断歪みが増加することが示され，これがせん 断変形の局所化と不安定化を導くことになる. Hirth ら は，水素の作用としてせん断変形による炭化物界面の剥 離を助長し, この剥離がさらに歪みの局所化を助長する 相乗効果を提案している. しかし, 微細ディンプルの起 点は確認されていない。

3.1 項で述べたように，延性き裂先端に第二相粒子を 伴わないで微小ボイドが生成することはいくつかの報告 があり, さらに原子空孔密度の増加でボイドが生成する ことも報告されている. 南雲らは低炭素フェライト鋼に 水素添加しながら引張り破断させ, 破面直下及びき裂先 端領域の組織を透過電子顕微鏡で観察している ${ }^{62)}$. 水素 添加は $3 \% \mathrm{NaCl}+3 \mathrm{~g} / \mathrm{L} \mathrm{NH}_{4} \mathrm{SCN}$ 水溶液, 電流密度 1 $\mathrm{mA} / \mathrm{cm}^{2}$ の陰極電解で, $12 \mathrm{~h}$ の予添加に継続して水素添 加と引張りを行っている. またきわめて局所的な観察試 料を採取するために FIB（focused ion beam）法を用いて いる. 図 $18^{62)}$ は破断面近くの試料表面に生成したき裂先 端の写真で, 明視野像（a）には円で示した領域の制限視 野電子線回折パターンも示してある. 電子線回折には八 ローパターンが表れ，非晶質化していることを示唆して いる。（b）はハローリングからの暗視野像で，非晶質域 がき裂先端に生成していることがわかる．非晶質化は破 面直下の $1 \mu \mathrm{m}$ 程度の領域及び内部の高転位密度領域の 転位セルに沿っても観察されている.

電子線回折のハローパターンだけでは非晶質かナノ結 晶かの区別は困難であるが, 高分解像でも不規則な原子 配列が観察され, 結晶が大きく崩れていることが明らか である。き裂進展が非晶質を伴っている観察例は少ない が，き裂先端域の非晶質化は水素脆性ではないが $\mathrm{NiTi}^{63}$ でも報告されている. 空孔密度が $10^{-4}$ 程度に増加するこ とによって非晶質化することは充分に予想されることで あり，非晶質合金の水素脆化は大きい。空孔密度の増加 が塑性不安定性を導いてき裂の進展を容易にしている可 能性が大きく, 水素はその作用を助長していると考えら れる。

\section{5. 遅れ破壊 〜応力緩和とクリープ〜}

上記のように, 水素脆性は引張りあるいは曲げ試験で 観察・評価されることが多い. 一方, 高強度鋼の水素脆 性としては高強度ボルトにみられるように使用中に破断 する遅れ破壊が知られており, 高強度鋼の実用上の大き な問題である。遅れ破壊については松山の著書64) や, 2 回にわたって行われた日本鉄鋼協会の共同研究会報告書 がある ${ }^{65), 66)}$. 遅れ破壊特性は材料強度や組織に敏感であ るが, 一般に破断時間や限界応力が水素量の増加によっ て低下することが多いので, 従来は侵入水素量に注目し た整理が主である。しかし，破壊現象としてみた場合に は材料の力学挙動から水素の作用を考察しなくてはなら ないが，遅れ破壊に対して従来はそのような扱いはほと んどない. 本報では遅れ破壊現象の一般的な特徽につい ては既書にゆずり，今までに述べてきた破壊過程におけ る水素の作用という統一的な観点から遅れ破壊の力学的 な扱いを取り上げる。遅れ破壊感受性の低減や機構解明 の新しい観点となろう。

\section{1 応力 緩 和}

遅れ破壊にはボルトの締め付けのような定変位条件 と, 実験室的にしばしば用いられる定荷重条件がある. 変位が一定の状態は動的には歪み速度が零の状態である が，全歪みは弾性歪み $\varepsilon_{\mathrm{e}}$ と塑性歪み $\varepsilon_{\mathrm{p}}$ の和だから，全 歪み速度零は弾性歪み速度と塑性歪み速度が逆符号で大 きさが等しい状態でもある．弾性変形の Hook の法則か 
ら Young 率を $E$ として，

$$
\begin{aligned}
& \varepsilon=\varepsilon_{\mathrm{e}}+\varepsilon_{\mathrm{p}}=\text { const } \\
& \therefore \quad \dot{\varepsilon}_{\mathrm{p}}=-\dot{\varepsilon}_{\mathrm{e}}=-\frac{\dot{\sigma}_{\mathrm{e}}}{E}
\end{aligned}
$$

である。これは塑性歪みの変化が弾性応力の変化として 表れる応力緩和現象にほかならない。すなわち, 定变位 の遅れ破壊試験では応力緩和があり, それに伴って塑性 変形が進行していることになる.

水素が応力緩和に及ぼす影響についてはいくつかの報 告がある. Lunarska は鉄試料の応力緩和試験中に水素添 加すると緩和速度が変化することを観察している．純鉄 単結晶試料（直径約 $3.5 \mathrm{~mm}$ ）をくびれが発生する前の 一様伸び域に引張って応力緩和を開始し，1.5〜 5 分後に 水素添加を始めると応力緩和速度が増大する ${ }^{67)}$. 水素添 加は $0.1 \mathrm{~N} \mathrm{H}_{2} \mathrm{SO}_{4}+3 \mathrm{mg} / \mathrm{L} \mathrm{As}_{2} \mathrm{O}_{3}$, 電流密度は $2 \sim 17$ $\mathrm{mA} / \mathrm{cm}^{2}$ である。一方, 多結晶低炭素鉄細線試料（直径 $1.4 \mathrm{~mm})$ では一様伸び域で応力緩和を開始して途中で水 素添加すると単結晶試料と同様に緩和速度が増大する が，くびれを起こした状態で応力緩和を開始すると水素 添加後にある潜伏時間を経て緩和速度が逆に小さくな り, 長時間後には破断にいたる ${ }^{68)}$. 陰極水素添加は $0.1 \mathrm{~N}$ $\mathrm{H}_{2} \mathrm{SO}_{4}+0.5 \mathrm{~g} / \mathrm{L} \mathrm{As}_{2} \mathrm{O}_{3}$, 電流密度は $0.4 \mathrm{~mA} / \mathrm{cm}^{2}$ である. 潜伏時間は 10 分程度でくびれが大きいと短くなる。ま た，くびれ部の水素濃度はほぼ一定である。

一方, Oriani と Josephic はパーライト組織の AISI 1045 鋼（厚さ $0.25 \mathrm{~mm}$ の平板試料）を用いて応力緩和 がある程度進行したところで水素添加し, 緩和速度に及 ぼす電流密度の影響を調べている ${ }^{69)}$, 70). 陰極電解液は $0.1 \mathrm{~N} \mathrm{NaOH}+10 \mathrm{mg} / \mathrm{L} \mathrm{As}_{2} \mathrm{O}_{3}$ である. 水素添加によって 緩和速度が増大するがその程度は電流密度に依存し，あ る限界電流密度以下では効果がない. 限界電流密度は水 素逃散能に換算すると応力緩和を開始させる初期歪みが $5 \%$ ときに $3.2 \mathrm{MPa}, 22 \%$ ば $7.4 \mathrm{MPa}$ 程度（電流密 度では $0.1 \mathrm{~mA} / \mathrm{cm}^{2}$ 以下）であるが, 初期歪みの増加に 伴って大きくなる. 逃散能への換算は水素透過試験から 求めた表面水素濃度に Sievert 則を適用したものである.

これらの実験では応力緩和で歪み速度の低下が定常的 になった後で水素添加を行っている．応力緩和試験では 変位増加を停止した直後に大きな荷重低下があるが，そ の段階に及ぼす水素の影響はみていない。また，限界電 流密度（逃散能）があることは水素が炭化物界面を剥離 し, それに伴う内部応力の低下が転位密度を増加させる としているが，不可逆的な損傷生成の検証はされていな い.

これらの研究の主な目的は水素と転位の kinetics との 関係で，例えば歪み速度を転位の粘性流動モデルで表す と, 転位速度 $v$ はせん断応力を $\tau$, 内部応力を $\tau_{\mathrm{i}}$ として $v=A\left(\tau-\tau_{\mathrm{i}}\right)^{m}$

と表され，応力指数 $m$ が水素添加すると小さくなる ${ }^{67)}$. $A$ は定数である. しかし, 粘性流動モデルが適切である 保証はない。緩和速度は試験温度に極めて敏感であり， 次項のクリープで述べるように転位運動は熱活性によっ て短範囲の障害を越える過程である可能性がある.

一方, 高強度鋼の遅れ破壊特性との関係について南雲 らは Mo-V マルテンサイト鋼 $(0.37 \mathrm{C}, 0.61 \mathrm{Si}, 0.20 \mathrm{Mn}$, $1.0 \mathrm{Mo}, 0.54 \mathrm{~V}, 0.51 \mathrm{Cr} ; \operatorname{mass} \%)$ の応力緩和特性を調べてい

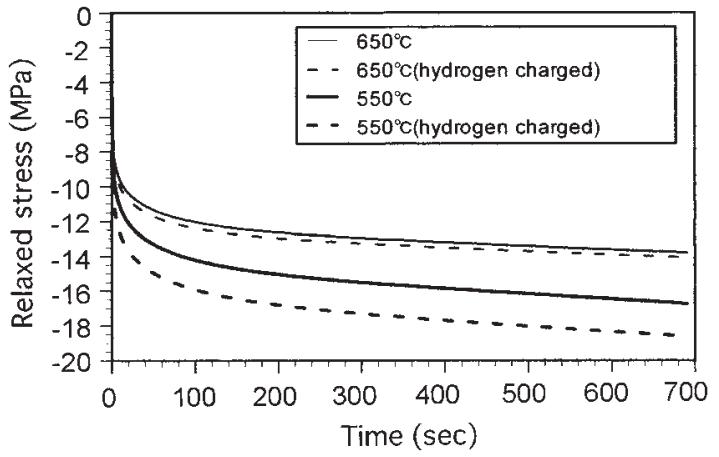

図 19 焼戻し温度を変えた Mo-V 添加マルテンサイト鋼の水素 添加有無における応力緩和曲線71).

緩和開始応力 : $0.6 \sigma_{\mathrm{B}}$, 試験温度 $: 28 \pm 0.5^{\circ} \mathrm{C}$.

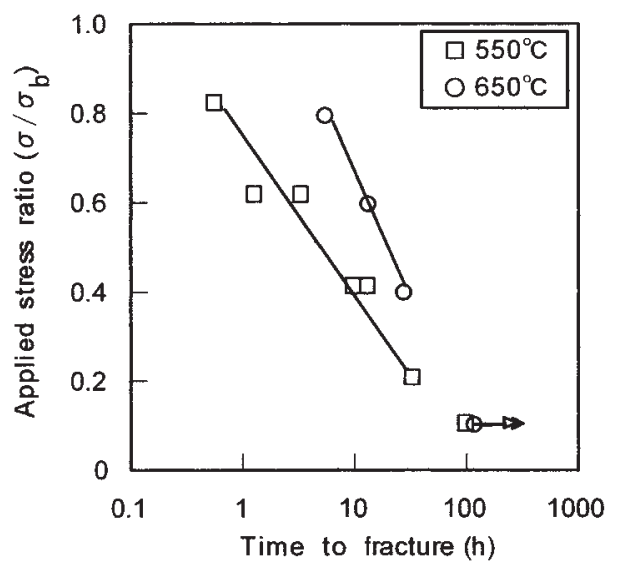

図 20 焼戻し温度を変えた Mo- $\mathrm{V}$ 添加マルテンサイト鋼の遅れ 破壊特性 ${ }^{71}$. 水素添加は $3 \% \mathrm{NaCl}+3 \mathrm{~g} / \mathrm{L} \mathrm{NH}_{4} \mathrm{SCN}$ 水溶 液，電流密度 $0.5 \mathrm{~mA} / \mathrm{cm}^{2}$ を用いた陰極電解.

る ${ }^{71)}$. この鋼は二次析出硬化を利用して強度を一定にし たまま組織を変えることが出来る，焼戻し温度が 450～ $650^{\circ} \mathrm{C}$ で硬さはほぼ一定であり, 高温焼戻しで V 炭化物 の微細析出がある。図 1971) は焼戻し温度が $550^{\circ} \mathrm{C}$ と $650^{\circ} \mathrm{C}$ の試料（厚さ $2 \mathrm{~mm}$ の平板試験片）を用いて引張 り試験中に変形を停止したときの応力緩和曲線を比較し たもので, 水素添加の効果も示されている. 水素は試験 直前の予添加で, 条件は $3 \% \mathrm{NaCl}+3 \mathrm{~g} / \mathrm{L} \mathrm{NH}_{4} \mathrm{SCN}$ 水溶 液, 電流密度 $0.5 \mathrm{~mA} / \mathrm{cm}^{2}$ で $8 \mathrm{~h}$ の陰極電解である。無 負荷試料の水素量は約 3 mass ppm で, 応力緩和試験中 の水素添加はない. 応力緩和開始の初期応力は引張り強 さ $\sigma_{\mathrm{B}}$ の 0.6 で, その応力值までは $2.8 \times 10^{-3} / \mathrm{s}$ の歪み速 度で到達させている. また, 応力緩和は試験温度に敏感 なので $28 \pm 0.5^{\circ} \mathrm{C}$ に制御してある。図にみられるように， 水素を予添加すると応力緩和が大きくなるが, 析出硬化 させた $650^{\circ} \mathrm{C}$ 焼戻し材は $550^{\circ} \mathrm{C}$ 焼戻し材に比べて応力緩 和が小さく，水素添加の影響も小さい.

この試料の遅れ破壊特性として上記と同じ厚さ $2 \mathrm{~mm}$ の平板試験片と陰極電解条件を用いて, 水素添加しなが ら定荷重遅れ破壊試験を行った結果が図 2071) である. 同 一強度でも析出硬化させた $650^{\circ} \mathrm{C}$ 焼戻し材では遅れ破壊 寿命が改善されている.これを応力緩和特性と対応させ （7）式を参照すると, 塑性歪み速度は転位密度と転位運 動速度の積に比例するから, 転位運動が不活発な, いい 
かえれば転位配列が安定化していることが遅れ破壊感受 性を低下させていることになる。一方, 析出強化したマ ルテンサイト鋼の水素トラップサイトは塑性変形の影響 も含めて複雑である. 水素吸蔵量は微細析出物によって 増加し, さらにこれも塑性歪みの影響を受ける.この場 合は単純に塑性変形による増加量をとってみても遅れ破 壊特性との対応はみられなかった。

\section{2 クリープ}

試料に弾性限以上の応力を急速にかけると応力一定の 状態で変形が進行するクリープ現象が起きる。一般に最 初の遷移クリープに続いて定常クリープ状態になる．室 温では多くの場合にクリープ歪みは実用的には問題にな らない程度で，定常クリープ速度も小さいがゼロではな い. 金属では材料内部に負荷によって転位密度の増加と すべりが起き，その応力に見合った転位配列が形成され る. 変形が進行すると加工硬化によって内部応力が高ま り，また転位の運動に対する短範囲の障害物によって転 位の運動は止まる。しかし, 熱エネルギーでバランスが くずれ，熱活性で塑性歪みが進行する.クリープ現象の 基本的な概念は例えば Cottrell の教科書72) に詳しい。

転位が熱活性の助けなしに動くことが出来る応力を “降伏応力” $\sigma_{\mathrm{y}}$ (強度特性としての降伏強さとは異なる) と定義すれば, 外部応力 $\sigma$ が $\sigma_{\mathrm{y}}$ 以下であっても熱エネル ギーがあれば動くことが出来る．しかし，クリープ歪み が大きくなると降伏応力が増加し, 障害を越えるのに必 要な活性化エネルギーも増加して一定值に近づく．運動 転位が障害を越えるには交差すべりによる迂回, 上昇運 動などがあり，障害が転位林の場合は転位の切り合いが ある. 活性化エネルギーはこれらの過程によって值が異 なることになる．

遷移クリープは一般に運動出来る転位が枯渇して短時 間で終わるが，温度がある程度高ければ内部応力の部分 的な回復がある. 定常クリープではクリープ速度 $\dot{\varepsilon}$ は温 度と外部応力 $\sigma$ の関数として実験的に

$$
\dot{\varepsilon}=K \exp \{-(U-b \sigma)\} / R T
$$

で表される． $b$ はバーガースベクトルである．上記の定 義のように降伏応力 $\sigma_{\mathrm{y}}$ を障害物の位置における転位運動 に対する抵抗力とすると, 活性化エネルギーには $\sigma_{\mathrm{y}}$ と障 害物から離れたところでの内部応力との差が問題になる が, 内部応力は場所によって一定ではない. Cottrell は 新しい論文73) で内部応力の変動があるときに転位が障害 物を外部応力 $\sigma_{\mathrm{ap}}$ で越えるときの活性化エネルギーUが

$$
U=2 b l \xi\left(\sigma_{\mathrm{y}}-\sigma_{\mathrm{ap}}\right)\left[\ln \left[\frac{\sigma_{\mathrm{y}}}{\sigma_{\mathrm{ap}}}\right]\right]^{1 / 2}
$$

と表されることを導いている。 $b$ はバーガースベクトル， $l$ は障害を越える転位線の長さ， $\xi$ は障害物の作用が働 く範囲である。ここでは障害物の作用 $\left(\sigma_{\mathrm{a}} / \sigma_{\mathrm{y}}\right)$ を中心か らの距離について Gauss 分布にとっている。この理論は 転位が障害物に近づくときに応力緩和が起きることを取 り入れたものである. その基本的に重要な事情は, 障害 物が転位林のように複数が近接して存在することと, 転 位セグメントの運動も集団として扱わなければならない ことである。すなわち，障害物が多いとひとつの障害を 越えるときに応力変動の作用がある領域が小さくなり, 障害物が単一で独立にある場合は広い領域が関わるから
両者では事情が異なる。また，ひとつの障害が越えられ ると荷重は転位のほかの部分にかかるので, 他の障害に 対する活性化が容易になる。

水素がクリープに及ぼす研究は少ないが, 飯井らは単 結晶及び多結晶鉄（板厚 $2 \mathrm{~mm}$ 程度の平板試料）を用い てクリープ試験中に水素添加してクリープ速度の変化を 調べている ${ }^{74)}$. 試験温度は $200 \mathrm{~K}$, 水素添加は陰極電解 で $70 \% \mathrm{CH}_{3} \mathrm{OH}+27.6 \% \mathrm{H}_{2} \mathrm{O}+2.4 \% \mathrm{H}_{2} \mathrm{SO}_{4}+10 \mathrm{mg} / \mathrm{L}$ $\mathrm{NaAsO}_{2}$ 液中 $0.5 \sim 30 \mathrm{~mA} / \mathrm{cm}^{2}$ の電流密度で行っている. $2 \mathrm{~mA} / \mathrm{cm}^{2}$ 程度でも水素添加によってクリープ速度は始 めにゆっくり増加した後で大きな増加を示し，ほぼ定常 状態になった後で減少する. クリープ速度の増加はクリ ープを開始する歪みが大きいと顕著である．水素添加を 中断するとクリープ速度は 2,3 分後に水素添加前の值に 戻る. また，水素添加してクリープさせた試料の内部に は変形の大きい場合に単結晶では主すべり系に，多結晶 では粒界に沿って微細なボイドや割れが観察されてい る.これらの現象は, 応力緩和試験と同様に, 水素が転 位速度を増加させるとともに割れの生成を助長すること を示唆している。

一方, Oriani らは炭化物を球状化させた AISI 1040 鋼 （試料直径 $0.12 \mathrm{~mm}$ ）を用いて室温のクリープ特性に及 ぼす水素添加の影響を調べている75). 水素添加は㓌極電 解で, $0.1 \mathrm{~N} \mathrm{NaOH}+10 \mathrm{mg} / \mathrm{L} \mathrm{As}_{2} \mathrm{O}_{3}$ 液中, 電流密度は文 献 69）と同様に水素逃散能に換算している.クリープの 進行は初期歪みを $\varepsilon_{0}$ として

$$
\varepsilon-\varepsilon_{0}=k \ln \left(t-t_{0}\right)
$$

と表される.クリープ試験中に水素添加するとクリープ 歪みは急速に増加するが，それには $40 \mathrm{MPa}$ 以上の逃散 能が必要である。クリープ歪みの増加はすぐに緩やかに なり，クリープ速度は始めの水素添加がない場合の值以 下になる．そこで水素添加を停止するとクリープ歪みは 増加するが立ち上がりは緩やかで, 水素添加の際の急速 な変化とは全く異なる．また，最初から充分に大きな逃 散能 (100 MPa) で水素添加しながら負荷してクリープを 開始したときは, クリープ速度は水素添加がない場合と ほとんど同じである．逃散能がある限界值以上で水素の 影響が表れることは，さきの応力緩和試験の結果 ${ }^{69)}$ と同 様で, 炭化物界面剥離によるとしている。水素添加でク リープ速度が大きくなるのは転位運動が助長されること になるが，すぐに小さくなるのは逆に加工硬化が助長さ れることにもなる.クリープ速度は転位速度に直接関わ る量であるが，クリープ歪みの変化が急速に起きる場合 には速度の決め方が難しく, また装置上の過渡現象もあ る.

以上のように応力緩和やクリープは遅れ破壊現象と深 く関わるものであるが，実験例は少なく，材料や実験条 件を系統づけて遅れ破壊特性との関係を調べる必要があ る. また, 解析方法も転位運動モデルによって異なるし, 試験中に材料内部で起きている変化を検出することも課 題である.

なお，試験温度が高くなるとクリープには空孔拡散の 効果が表れる. Xu と McLellan は多結晶純 Pd 試料（直 径 $0.1 \mathrm{~mm}$ ）を用いて 736〜 $1200 \mathrm{~K}$ の温度で $0.1 \mathrm{MPa}$ の $\mathrm{Ar}$ と $\mathrm{H}_{2}$ 雾囲気におけるクリープを測定している76). Ar 雾囲気中に比べて $\mathrm{H}_{2}$ 䨌囲気ではクリープの途中で水素 


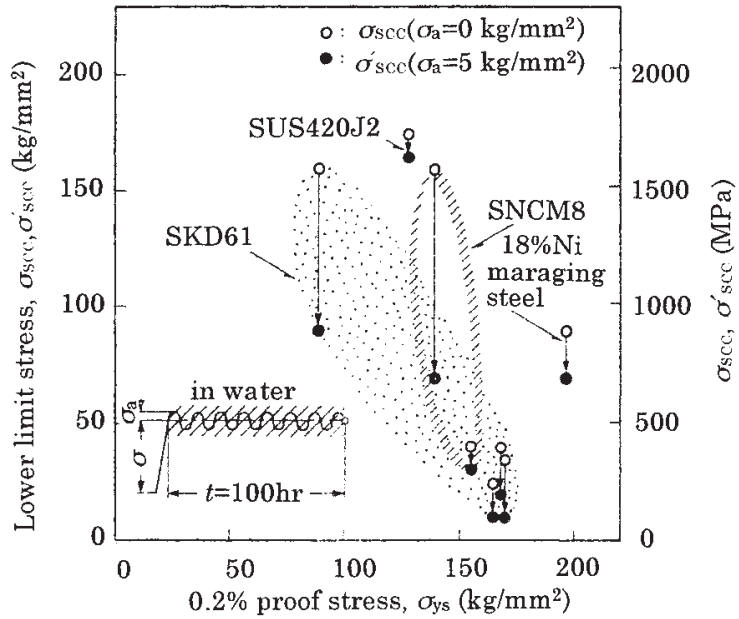

図 21 いろいろな鋼の変動応力付加による遅れ破壊下限応力の 低下 ${ }^{80)}$

を導入した場合を含めてクリープ速度が約 6 倍に増加す る.クリープ速度と応力及び試験温度との関係から，ク リープは粒界に沿う空孔の拡散で支配される Coble 型と 推定され， $\mathrm{H}_{2}$ 䨌囲気での活性化エネルギーは $30.0 \pm 1.5$ $\mathrm{kJ} / \mathrm{mol}$ で, $\mathrm{Ar}$ 雾囲気中の $38 \pm 1.9 \mathrm{~kJ} / \mathrm{mol}$ から大きく低 下している. 以前に述べたように ${ }^{77)}$, 水素は空孔と結合 して空孔生成エネルギーを低下させて空孔密度を増加さ せるので, 水素によるクリープ速度の増加は空孔密度の 増加として理解される.しかし，これは合金の種類や試 験温度によって異なる。 Ni-Fe 合金では $\mathrm{Ni}$ が多い組成で 900 1200 K におけるクリープ寿命が $\mathrm{H}_{2}$ 雲囲気では $\mathrm{He}$ 雲囲気と比べて大きく減少するが78)，クリープ速度はク リープの stage や合金組成によって単純ではない。

\section{3 遅れ破壊寿命に及ぼす環境変動の効果}

構造部材の使用中には負荷荷重や環境の変動を受ける 場合が多く, 遅れ破壊でもこれらの影響を検討する必要 がある．腐食環境における疲労は腐食疲労として疲労寿 命の減少が起きる．定応力における遅れ破壊は静疲労と も呼ばれるが，中佐らは SNCM8 鋼（TS : $1800 \mathrm{MPa）の}$ 片側切欠きつき試料に一定の曲げ応力をかけた状態で応 力を周期的に変動（15及び $40 \mathrm{cpm}$ の正弦波）させ，き 裂発生時間の変化を測定している ${ }^{79)}$. 応力レベルや変動 振幅, 周波数によって程度は異なるが, 一般に応力を変 動させると静疲労の場合に比べてき裂発生までの時間は 短くなり，切欠き部分に水を滴下すると顕著になる。下 限き裂発生応力も大きく低下する. 変動応力の効果は静 応力の $10 \%$ 以下の変動振幅でも表れ, 周波数の高い方 が効果が大きい．木戸らはさらに鋼種によってこの変動 応力の効果の程度が異なることを調べている ${ }^{80)}$ 。図 $21^{80)}$ はその結果で, 直径 $7 \mathrm{~mm}$ の試料について水滴添加にお ける静疲労と $5 \mathrm{~kg} / \mathrm{mm}^{2}$ の変動応力振幅を付加した場合 の下限き裂発生応力を比較したものである.

一方，井筒らはプレストレス鋼棒 (TS $1473 \mathrm{MPa}$ のマル テンサイト組織, 試料直径 5 または $7 \mathrm{~mm}$ )を FIP 試験 液 $\left(50^{\circ} \mathrm{C}\right.$ の $20 \% \mathrm{NH}_{4} \mathrm{SCN}$ 水溶液) 中で引張り型の遅れ破 壊試験を行い, その際に応力変動を与える効果を調べて いる ${ }^{81)}$. 応力変動は 5 及び $10 \mathrm{cpm}$ の台形波形で, 応力

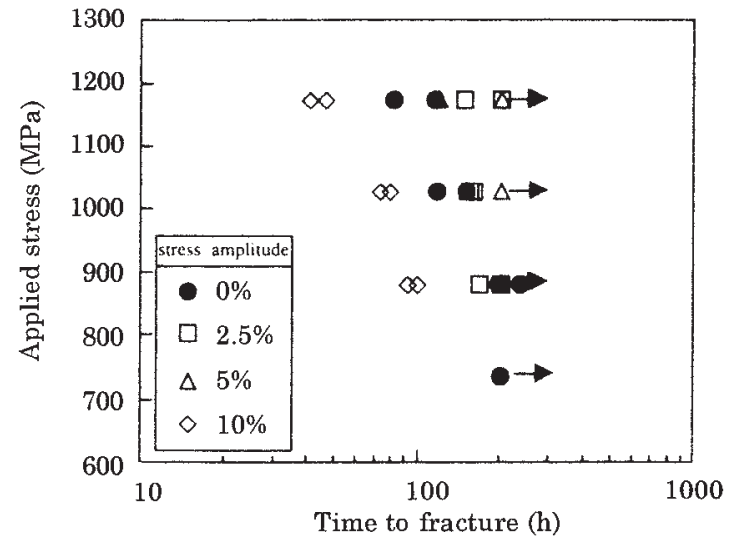

図 22 負荷応力を変動させたときの高強度鋼の FIP 試験遅れ破 壊寿命の低下 ${ }^{81}$.

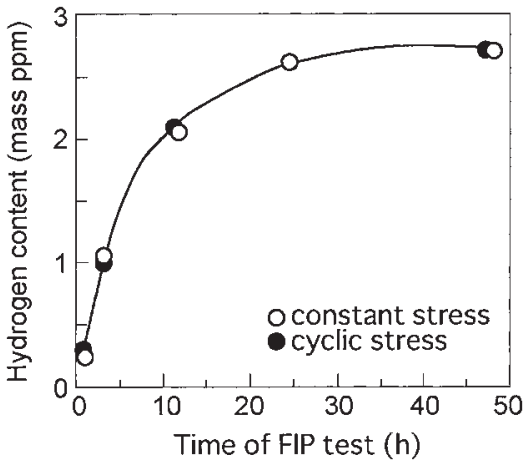

図 23 FIP 遅れ破壊試験中の水素侵入量に及ぼす負荷応力変動 の効果 ${ }^{81}$.

を変動させるても最大応力は一定になるように注意して いる. 図 $22^{81)}$ は直径 $7 \mathrm{~mm}$ の試料の遅れ破壊試験結果で, $10 \%$ 変動応力を与えると破断寿命が減少し, 同様の結 果は直径 $5 \mathrm{~mm}$ の試料でも観察されている. 平均負荷応 力は応力変動によって図の負荷応力值よりも低く, また 破断までのサイクル数は $10^{5}$ 以下で通常の疲労寿命より もはるかに少ない. 試験中に侵入する水素量を測定した 結果は図 $23^{81)}$ に示したように浸漬時間で決まり, 変動応 力の付加による侵入水素量の増加は認められない.

一方，さきに示したように ${ }^{77), ~}$ 塑性歪みを与えると試 料の水素吸蔵量は増加し, 変形後に $200^{\circ} \mathrm{C}$ 程度の焼なま しを施すとその増加効果は消失する。 そこで, $0.5 \sigma_{\mathrm{B}}$ の 負荷応力で $48 \mathrm{~h}$ の FIP 試験を行った試料と, 試験後に $200^{\circ} \mathrm{C} ， 30 \mathrm{~min}$ の焼なましを施してから FIP 液に $48 \mathrm{~h}$ 浸 漬して水素を再添加した試料の昇温放出量を比較した. 低温焼なましにより遅れ破壊試験中に生成した空孔性の 点欠陥は消失しているとしてよい. したがって再水素添 加では欠陥の消失分だけ水素吸蔵量は減少することにな る. 遅れ破壊試験直後の試料と試験後に焼なまし処理を 施してから水素を再添加した試料について $200^{\circ} \mathrm{C}$ までに 放出される水素量の差をとると, 一定応力負荷の場合に は $0.642 \mathrm{ppm}, 10 \%$ の変動応力を付加した場合には 0.728 $\mathrm{ppm}$ となり, 変動応力を付加すると焼なましで消失する 欠陥量が増加していることになる.しかし，この差は水 素量としてはわずかであり, 水素脆化感受性との関係は 分析精度とともに水素量の持つ意味を慎重に検討しなけ 


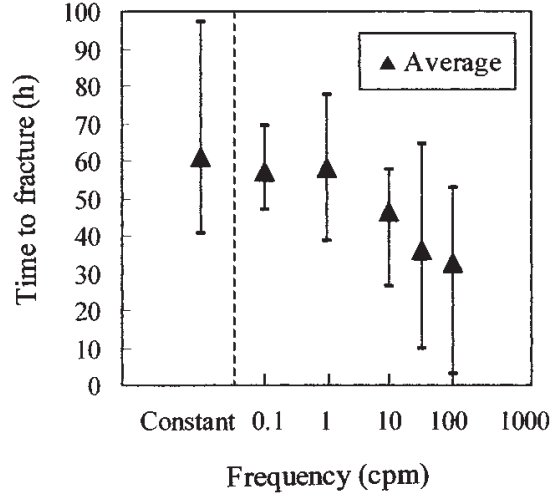

図 24 水素添加電流密度を変動させたときの高強度鋼の遅れ破 壊寿命の低下 ${ }^{83}$.

負荷応力： $0.7 \sigma_{\mathrm{B}}$, 電流変動振幅：10\%

ればならない，水素脆性機構と関連して次報で述べる.

環境変動としては他に水素添加条件の変動がある．前 報82) で紹介したように乾湿繰り返しにより水素侵入が促 進され, $\mathrm{pH}$ や表面皮膜の変化など材料表面の電気化学 反応から説明されている. 一方, 定応力遅れ破壊試験で 水素添加を陰極電解で行い，その際に電流密度を周期的 に変動させると破断時間が短くなることが南雲らによっ て見出されている ${ }^{83)}$. 試料は高強度マルテンサイト鋼

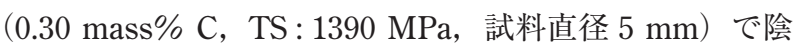
極電解は $3 \% \mathrm{NaCl}+3 \mathrm{~g} / \mathrm{L} \mathrm{NH}_{4} \mathrm{SCN}$ を用い, 電流密度は 最大值を一定にして振幅を変えた正弦波で変動させてい る.

図 $24^{83)}$ は最大電流密度を $0.75 \mathrm{~mA} / \mathrm{cm}^{2}$ として $10 \%$ の 変動を与えた場合の破断時間で，電流変化の周波数を 0.1 100 cpm に変化させている. 負荷応力は引張り強さ の 0.7 である.ばらつきが大きいが，水素添加条件を変 動させると早期に破断するようになり，その効果は周波 数が大きいほど顕著になる. 同一添加条件における水素 吸蔵量は負荷によって増加しているが，電流変動の影響 は認められていない。一方, 昇温分析曲線のプロファイ ルは水素添加時間によって変化する. 負荷材と無負荷材 の放出曲線の差をとると, 負荷材の水素吸蔵量増加は始 めは放出ピークの低温部分で起きるが添加時間が長くな ると代わって高温部が増加するようになる。そして電流 変動を与えた場合はその移行が早くに起きている。同様 な遅れ破壊特性と水素昇温放出曲線の形の変化との関係 は，焼戻し温度を変えたマルテンサイト鋼 ${ }^{84)}$, 予疲労を 与えた高強度ばね鋼85) などでも観察されている。この現 象は水素のトラップ状態，あるいは水素をトラップする 欠陥の状態が水素の添加, あるいは環境条件の変動によ って変化することを示唆している，遅れ破壊は塑性変形 を伴う動的な現象であり，その過程における水素の作用 を考察しなくてはならない.

\section{6. ま と め}

水素が関わったときに通常の䨌囲気における破壊がど のように影響を受けるのか, 破壊過程に分解しながら主 に現象面から全体的に整理してみた。破面パターンは一 般に tear ridge を伴って微細になり，脆性破面とみられ
るものでも塑性変形の痕跡がある. 破面全体としては平 坦化し，き裂は広い範囲の塑性変形を伴わずに進展して いる．水素によって延性き裂の発生が早期に起こり，き 裂進展抵抗も低下する。 $\mathrm{R}$ 曲線とその解析から，き裂先 端にボイド生成につながる歪みとそれに伴う久陷の生成 が水素の存在によって局所的に促進され, 破面の特徴と 一致する. 延性破壊の前駆現象として塑性不安定性があ るが，水素はそれを助長する．特徵的な水素脆性である 遅れ破壊には力学的プロセスとして応力緩和やクリープ があるが，これらは水素によって助長される。これらの 特徵は延性破壊過程で一般的に起きる転位の相互作用に 伴うナノスケールの損傷〜原子空孔性欠陥〜生成を水素 が助長するとして理解される。

\section{参 考 文 献}

1) M. Nagumo, Tetsu-to-Hagane, 66, 1696 (1980).

2) M. Nagumo, Tetsu-to-Hagane, 90, 756 (2004).

3) E. Lunarska, in "Hydrogen Degradation of Ferrous Alloys", Eds. R. A. Oriani, J. P. Hirth and M. Smialowski, pp. 321352, Noyes Pub., Park Ridge N.J., (1985).

4) J. F. Knott, "Fundamentals of Fracture Mechanics", pp.6572, 98-113, Butterworths Pub., London, (1973).

5) A. S. Tetelman and W. D. Robertson,.Trans. AIME, 224, 775 (1962).

6) F. Terasaki, T. Kawakami, A. Yoshikawa and N. Takano, Rev. Métall-CT/Sci. Génie Matér., 1519(1998).

7) M.-J. Lii, X.-F. Chen, Y. Katz and W. W. Gerberich, Acta Metall. Mater., 12, 2435 (1990).

8) T. J. Marrow, M. Aindow, P. Prangnell, M. Strangwood and J. F. Knott, Acta Mater., 44, 3125 (1996).

9) F. Nakasato and I. M. Bernstein, Metall. Trans. A, 9A, 1317 (1978).

10) H. Takahashi, T. Takeyama, T. Hara, J. Jpn. Inst. Metals, 43, 492 (1979).

11） M. Nagumo and K. Miyamoto, J. Jpn. Inst. Metals, 45, 1309 (1981).

12) M. Nagumo, Zairyo-to-Kankyo, 55, 42 (2006)

13) M. Aoki, H. Saito, M. Mori, Y. Ishida and M. Nagumo, J. Jpn. Inst. Metals, 58, 1141 (1994).

14) D. G. Ulmer and C. J. Altstetter, Acta Metall. Mater., 39, 1237 (1991).

15) J. A. Gordon, J. P. Hirth, A. M. Kumar, and N. E. Moody, Jr., Metall. Trans. A, 23A, 1013 (1992).

16) Y. Shimomura and M. Nagumo, in "Environment-Induced Cracking of Materials: Chemistry, Mechanics and Mechanisms”, Eds. S.A. Shipilov, R.H. Jones, J.M. Olive, R.B. Rebak, pp. 285-294, Elsevier, Oxford, (2007).

17) Y. H. Kim and J. W. Morris, Jr., Metall. Trans. A, 14A, 1883 (1983).

18) K. Yoshino and C. J. McMahon, Jr., Metall. Trans., 5, 363 (1974).

19) G. M. Ludtka and D. E. Laughlin, Metall. Trans A., 13A, 411 (1982).

20) M. Nagumo and H. Matsuda, Phil. Mag. A, 82, 3415 (2002).

21) T. Inoue, K. Yamamoto and M. Nagumo, in "Hydrogen Effects in Metals", Eds. I. M. Bernstein and A. W. Thompson, pp. 777-784, Metall. Soc. AIME, Warrendale PA, (1981).

22) H. Fuchigami, H. Minami and M. Nagumo, Phil. Mag. Lett., 86, 21 (2006).

23) C. D. Beachem, Metall. Trans., 3, 437 (1972).

24) F. Terasaki and N. Takano, Materia (Bull. Jpn. Inst. Metals), 7, 922 (1994).

25）矢川元基編，破壊力学，培風館，東京，(1988）.

26) R. H. van Stone, J. R. Low, Jr. and J. L. Shannon, Jr., Metall. Trans., 9A, 539 (1978).

27) R. L. Lyles and H. G. F. Wilsdorf, Acta Metall., 23, 269 (1975)..

28） R. N. Gardner and H. G. F. Wilsdorf, Metall. Trans. A, 11A, 659 (1980).

29) A. M. Cuitin̆o and M. Ortiz, Acta Mater., 44, 427 (1996). 
30) R. H. van Stone, T. B. Cox, J. R. Low, Jr. and J. A. Psioda, Int. Metals Rev., 30, 157 (1985).

31) F. A. McClintock, Trans. ASME, J. Appl. Mech., 35, 363 (1968).

32) H. C. Rogers, Trans. TMS-AIME, 218, 498 (1960)

33) T. B. Cox and J. R. Low, Metall. Trans., 5, 1457 (1974).

34) P. F. Thomason, J. Inst. Metals, 96, 360 (1968).

35) P. F. Thomason, Acta Metall., 29, 763 (1981).

36) A. Needleman and V. Tvergaard, J. Mech. Phys. Solids, 35, 151 (1987).

37) P. C. Paris, H. Tada, A. Zahoor and E. Ernst, in "ElasticPlastic Fracture”, pp.5-36, ASTM STP-668, ASTM, Philadelphia, (1979).

38) “Standard Practice for R-Curve Determination", ASTM Standard E-561-81.

39） J. R. Rice, J. Appl. Mech., 35, 379 (1968).

40）弾塑性破壊䩲性 J IC 試験方法, 日本機械学会 (1992).

41) J. R. Rice, P. C. Paris and J. G. Merkle, in "Progress in Flaw Growth and Fracture Toughness Testing”, pp. 231245, ASTM STP-536, ASTM, Philadelphia, (1973).

42) M. Koide, A. Kikuchi, T. Yagi and M. Nagumo, Mater. Sci. Eng. A, A176, 171 (1994)

43) Y. Fujii, A. Kikuchi and M. Nagumo, Metall. Mater. Trans. A, 27A, 469 (1996).

44) R. O. Ritchie and A. W. Thompson, Metall. Trans. A, 16A, 233 (1985).

45) T. Yagi, A. Itoh and M. Nagumo, Tetsu-to-Hagane, 81, 225 (1995).

46) M. Nagumo, T. Yagi and H. Saitoh, Acta Mater., 48, 943 (2000).

47) Fig. 2.4 in M. Nagumo, Zairyo-to-Kankyo, 54, 251 (2005).

48) A. L. Gurson: Trans. ASME, J. Eng. Mater. Tech., 99, 2 (1977).

49) A. L. Gurson: Fracture 1977, vol. 2A, 357, Oxford Press (1978)

50) H. Yoshida and M. Nagumo, ISIJ Int., 38, 196 (1996).

51) M. Nagumo, H. Yoshida, Y. Shimomura and T. Kadokura, Mater. Trans., 42, 132 (2001)

52) K. Minoshima, Y. Oie and K. Komai: ISIJ Int., 43, 579 (2003).

53) V. J. Russo, A. K. Chakrabarti and J. W. Spretnak, Metall. Trans. A, 8A, 729 (1977).

54) O. A. Onyewuenyi and J. P. Hirth, Metall. Trans. A, 14A, 259 (1980).

55) Rogers, Ann. Rev. Mater. Sci., 9, 283 (1979).

56) O. A. Onyewuenyi, in "Hydrogen Degradation of Ferrous Alloys”, Eds. R. A. Oriani, J. P. Hirth and M. Smialowski, pp. 414-453, Noyes Pub., Park Ridge N.J. (1985).

57) R. J. Price and A. Kelly, Acta Metall., 12, 979 (1964).

58) I-G. Park and A. W. Thompson, Metall. Trans. A, 21A, 465 (1990).

59) I-G. Park and A. W. Thompson, Metall. Trans. A, 22A, 1615 (1991).

60) J. A. Gordon, J. P. Hirth, A. M. Kumar, and N. E. Moody,
Jr., Metall. Trans. A, 23A, 1013 (1992).

61) J. P. Hirth, in "Hydrogen Effects in Materials", Eds. A. W. Thompson and N. R. Moody, pp. 507-522, TMS, Warrendale, (1996)

62) M. Nagumo, T. Ishikawa, T. Endoh and Y. Inoue, Scr. Mater., 49, 837 (2003).

63) P. R. Okamoto, J. K. Heuer, N. Q. Lam, S. Ohnuki, Y. Matsuokawa and K. Tozawa, Appl. Phys. Lett., 73, 473 (1998).

64）松山晋作，“遅れ破壊”，日刊工業新聞社（1989）。

65）“水素による遅れ破壊の機構”, 鉄鋼基礎共同研究会遅 れ破壊部会報告書，日本鉄鋼協会 (1975)。

66）“遅れ破壊解明の新展開”，日本鉄鋼協会（1997）. “Advances in Delayed Fracture Solution”, Iron Steel Inst. Japan, Tokyo, (1997).

67) E. Lunarska, Scr. Metall., 11, $283(1977)$.

68) E. Lunarska, Acta Metall., 26, 1805(1978).

69) R. A. Oriani and P. H. Josephic, Acta Metall., 27, 997 (1979)

70) R. A. Oriani, in "Hydrogen Degradation of Ferrous Alloys", Eds. R. A. Oriani, J. P. Hirth and M. Smialowski, pp. 353365, Noyes Pub., Park Ridge N.J. (1985).

71) M. Nagumo, T. Tamaoki and T. Sugawara, in "Hydrogen Effects on Materials Behavior and Corrosion Deformation Interactions”, Eds. N. R. Moody, A. W. Thompson, R. E. Ricker, C. W. Was and K. H. Jones, pp. 999-1008, TMS, Warrendale PA, (2003)

72) A. H. Cottrell, "Dislocations and Plastic Flow in Crystals", Chap. 16, Oxford Univ. Press, London, (1956).

73) A. H. Cottrell, Phil. Mag. Lett., 82, 65 (2002).

74) J. Nagakawa, K. S. Shin, C. G. Park and M. Meshii, in "Hydrogen in Metals", Suppl. Trans. Jpn. Inst. Metals, 21, 549 (1979).

75) R. A. Oriani and P. H. Josephic, Acta Metall., 29, 669 (1981).

76) Z. R. Xu and R. B. McLellan, Acta Mater., 46, 4543 (1998).

77) M. Nagumo, Zairyo-to-Kankyo, 54, 251 (2005).

78) G. B. A. Schuster, R. A. Yeske and C. J. Altstetter, Metall. Trans. A, 11, 1657 (1980)

79) K. Nakasa, M. Kido and H. Takei, J. Jpn. Inst. Metals, 40, 744 (1976).

80) M. Kido, K. Nakasa and H. Takei, Tetsu-to-Hagane, 65, 535 (1979).

81) K. Izutsu, K. Takai and M. Nagumo, Tetsu-to-Hagane, 83, 371 (1997).

82) M. Nagumo, Zairyo-to-Kankyo, 55, 430 (2006)

83) M. Nagumo, H. Uyama and M. Yoshizawa, Scr. Mater, 44, 947 (2001).

84) M. Nagumo, M. Nakamura and K. Takai, Metall. Mater. Trans. A, 32A, 339 (2001).

85) M. Nagumo, S. Sekiguchi, H. Hayashi, K. Takai, Mater. Sci. Eng A, A344, 86 (2003).

(2006 年 9 月 12 日受理)

水素脆性破壊の特徵を主に実験結果からまとめた。水素が作用する破壊過程を明らかにするために，通 常の破壊と比べて異なる点に注目した．破面形態の特徵や R 曲線の解析から調べたき裂の発生及び進展過 程を示した。水素による塑性不安定性の助長も破壊の前駆過程として取り上げた。遅れ破壊の力学的側面 として応力緩和やクリープを紹介し，また外部応力や水素ポテンシャルなどの環境変動の効果についても 述べた。

キーワード＼cjkstart水素脆性, 延性破壊, 脆性破壊, 破面, $\mathrm{R}$ 曲線, 水素脆性破面, 塑性不安定性, 遅れ破 壊, 応力緩和, クリープ 